Article

\title{
Recycling and Application of Mine Tailings in Alkali-Activated Cements and Mortars-Strength Development and Environmental Assessment
}

\author{
Nuno Cristelo ${ }^{1, *(1)}$, João Coelho ${ }^{1}$, Mafalda Oliveira ${ }^{2}$, Nilo Cesar Consoli ${ }^{3}{ }^{[}$, Ángel Palomo ${ }^{4}$ \\ and Ana Fernández-Jiménez ${ }^{4}$ (D) \\ 1 CQVR, Department of Engineering, University of Trás-os-Montes e Alto Douro, 5001-801 Vila Real, Portugal; \\ jdc.coelho@gmail.com \\ 2 SOMINCOR, S.A., 7780-909 Castro Verde, Portugal; mafalda.oliveira@lundinmining.com \\ 3 Federal University of Rio Grande do Sul, 90040-060 Porto Alegre, Brazil; consoli@ufrgs.br \\ 4 Eduardo Torroja Institute for Construction Science (IETcc- C.S.I.C.), 28033 Madrid, Spain; \\ palomo@ietcc.csic.es (Á.P.); anafj@ietcc.csic.es (A.F.-J.) \\ * Correspondence: ncristel@utad.pt; Tel.: +351-259-350-793
}

Received: 23 January 2020; Accepted: 11 March 2020; Published: 19 March 2020

check for updates

\begin{abstract}
Mine tailings (MT) could represent a step forward in terms of the quality of the aggregates usually used in civil engineering applications, mostly due to its high density. The Portuguese Neves Corvo copper mine, owned by the Lundin Mining Corporation, produces approximately 3 million tonnes per year. Nevertheless, it cannot be used in its original state, due to its high levels of sulphur and other metals (As, $\mathrm{Cr}, \mathrm{Cu}, \mathrm{Pb}, \mathrm{Zn}$ ). This paper focuses on the stabilisation/solidification of high-sulphur MT, without any previous thermal treatment, using alkali-activated fly ash (FA). The variables considered were the MT/FA ratio and the activator type and concentration. A fine aggregate was then added to the pastes to assess the quality of the resulting mortar. Maximum compressive strengths of $14 \mathrm{MPa}$ and $24 \mathrm{MPa}$ were obtained for the pastes and mortars, respectively, after curing for $24 \mathrm{~h}$ at $85^{\circ} \mathrm{C}$. Thermogravimetric analysis, scanning electron microscopy, $\mathrm{X}$-ray energy dispersive spectroscopy, X-ray diffraction, and infrared spectroscopy were used to characterize the reaction products, and two types of leaching tests were performed to assess the environmental performance. The results showed that the strength increase is related with the formation of a N-A-S-H gel, although sodium sulphate carbonate was also developed, suggesting that the total sodium intake could be optimized without strength loss. The solubility of the analysed metals in the paste with 78\% MT and $22 \%$ FA was below the threshold for non-hazardous waste.
\end{abstract}

Keywords: recycling; wastes; alkaline activation; compressive strength; leaching tests; microstructural characterisation

\section{Introduction}

The framework addressing the sustainability optimisation of the mining sector is currently undergoing a very significant revolution. It is abandoning the focus on the efficiency of operations, aiming to reduce the disposed waste, and shifting to a more global paradigm, encompassing not only the mining operations but also the complete life cycle of this vital industry [1]. Wastes resulting from mining operations can result either from crushing or other, more complex processing methods. The former, normally referred to as plain "mining waste", has been used in the construction industry (e.g., concrete, embankments) as it does not raise any special environmental concerns; the latter, usually referred to as "mine tailings" (MT), produces more worrying materials due to its high levels of different kinds of contaminants which can be washed away when in contact with water [2-4]. Nevertheless, the 
potential use of MT as a replacement for natural aggregates, which are usually obtained through an extraction process that severely affects the environment, would not only reduce the consumption of natural resources but also decrease the volume of landfilled MT. However, this waste generates acid mine drainage when exposed to oxygen and water [5], which makes it impractical as an aggregate in common applications, like embankments or roads, if not previously stabilised.

Another possible use is inclusion in alkali-activated mortar and concrete, a recent research topic, with promising results in terms of mechanical and environmental performance $[5,6]$. Some studies focused on the use of MT as a precursor, albeit requiring a previous thermal treatment [7-11], while others used a different approach by considering the MT as a filler and/or coarse aggregate in composite materials, cemented by aluminosilicate gel formed from the alkali activation of fly ash, metakaolin, waste glass, or slags [11-19]. Although many of the above-mentioned studies were dealing with tailings resulting from tungsten and gold mines, several studies have also been produced targeting copper mine tailings [16,19-23]. From an environmental perspective, it is important to highlight that alkaline activation has already proved to be very effective for containing and neutralising different types of wastes [24-35] and, specifically, wastes resulting from mine operations [36-39], a capacity that reinforces the potential for this technique to stabilise mine tailings.

Nevertheless, a decisive breakthrough has yet to be achieved, one might say. Alkali activation for mine tailings stabilisation, for an industrial application or landfilling, is not yet a common option because of the logistical difficulties associated with the implementation of such an operation. This is not related with its technical efficiency. For instance, for applications to roads or railway pavements we would need to consider the distance between the mine and the work site, especially if an adequate aggregate can be found nearby. A similar assessment needs to be made regarding mortar or concrete production, i.e., why not use closer and cheaper materials which do not require any sort of chemical stabilisation/enhancement, instead of this waste which, albeit a very competent material, needs to be previously treated? The obvious, most direct solution for this logistical difficulty is the installation of industrial units near the mine for the prefabrication of structural components (e.g., reinforced beams, masonry bricks) or nonstructural elements, like urban furniture or façade panels. Some studies have already started to focus on specific applications, namely, the production of bricks. Kuranchi et al. [40], when studying the production of geopolymer bricks from iron ore mine tailings, reported cost reductions of $20 \%$ to $36 \%$ relative to conventional clay bricks, as well as significant environmental benefits. Ahmari and Zhang [20] successfully used cement kiln dust to optimise the strength and durability of MT-based geopolymer bricks. However, even if the number of research projects addressing the stabilisation of MT through alkaline activation is increasing, more studies are required to fully understand the complex role that some nonconventional elements usually found in MT (e.g., heavy metals, sulphur) can have in alkaline activation reactions and, consequently, how they can influence both mechanical and environmental performance.

The Neves Corvo underground copper-zinc mine, located $200 \mathrm{~km}$ south of Lisbon, produces 2.9 million tonnes of tailings annually, of which approximately two-thirds are landfilled. It is a world-class mine due to the extremely high copper and zinc contents. Its requires a continuous financial and technical effort to guarantee safe and sound deposits, and currently constitutes the single major concern associated with this type of mineral exploration. In this paper we focused on the stabilisation of the copper mine tailings produced at Neves Corvo using alkali-activated fly ash (FA), and a sandy aggregate was subsequently added to form a mortar with a waste content of $50 \%$ (MT+FA). The MT was mixed with the FA under different FA/MT weight ratios and activated with a combination of sodium hydroxide and sodium silicate. Additional variables tested were the sodium hydroxide concentration and the hydroxide/silicate weight ratio. Mechanical behaviour was assessed through uniaxial compressive strength tests, while microstructural and mineralogical characterisation was achieved using thermogravimetry, scanning electron microscopy, X-ray energy dispersion, X-ray diffraction, and infrared spectroscopy. Leaching tests were conducted to determine the concentration 
of toxic elements present in the stabilised mortars, and the values obtained were compared with the thresholds imposed by European standards.

\section{Materials and Methods}

Two types of mixtures were studied: binding pastes, based on a combination of mine tailings (MT) and activated fly ash (FA), and mortars, comprising the same MT- and FA-based pastes, but including also a fine aggregate. These mixtures were designed so as to study the mechanical and environmental stabilisation of the MT through alkali-activated FA and the influence on the mechanical behaviour of a medium-sized sand skeleton.

\subsection{Materials}

The mining waste was collected at the Neves Corvo mine, operated since 1988 by SOMINCOR (Sociedade Mineira de Neves Corvo S.A.), owned by the Lundin Mining Corporation. It was mostly included as an inert, in terms of alkaline activation reactions, and not as a precursor, and was recovered from one of the ponds located inside the mine compound (Figure 1), i.e., with a high water content. It was immediately transported to the laboratory, where it was separated from most of the constituent water and mixed with different percentages of FA, provided by the company PEGOP, responsible for the Portuguese thermo-electric power plant Central do Pego. The aggregate was a sandy soil (GS), collected on a bank of the river Tâmega, located in the region of Chaves in the north of Portugal.

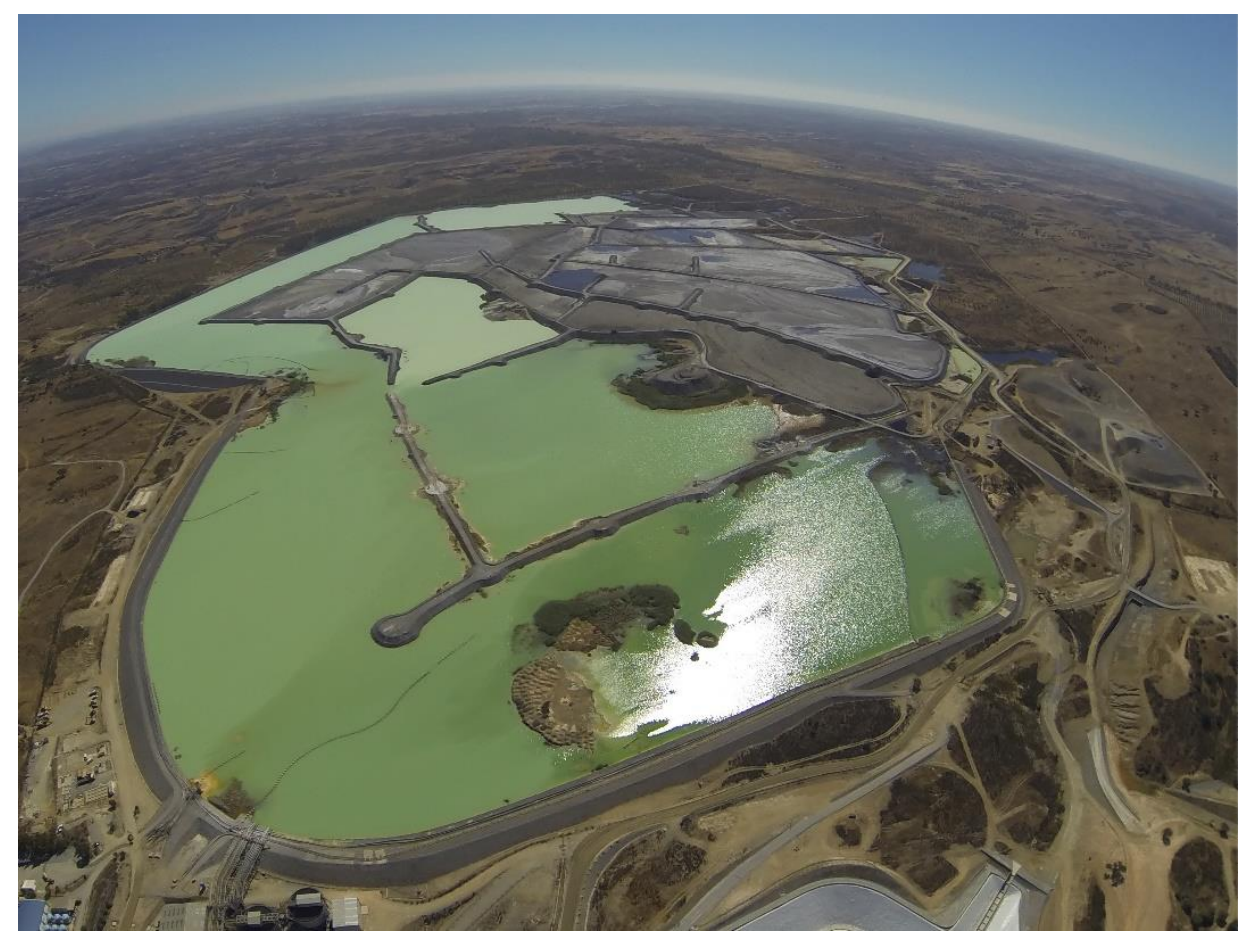

Figure 1. General view of the ponds.

The chemical composition of the three materials, obtained by X-ray fluorescence (XRF), is shown in Table 1. The main elements of the MT are sulphur trioxide $(41 \%)$ and iron $(28 \%)$, although some heavy metals were also detected in smaller percentages. The FA presented mostly silica $(45.2 \%)$ and alumina $(28.5 \%)$. Finally, the aggregate, as expected, was basically silica $(86.8 \%)$. 
Table 1. Chemical composition.

\begin{tabular}{|c|c|c|c|}
\hline Element & Fly Ash & Tailings & Soil \\
\hline & $(w t \%)$ & $(w t \%)$ & $(w t \%)$ \\
\hline $\mathrm{Na}_{2} \mathrm{O}$ & 1.18 & 0.41 & 0.47 \\
\hline $\mathrm{SiO}_{2}$ & 45.2 & 18.5 & 86.77 \\
\hline $\mathrm{Al}_{2} \mathrm{O}_{3}$ & 28.5 & 7.25 & 7.20 \\
\hline $\mathrm{MgO}$ & 1.07 & 1.48 & 0.11 \\
\hline $\mathrm{K}_{2} \mathrm{O}$ & 1.56 & 0.61 & 4.02 \\
\hline $\mathrm{CaO}$ & 6.04 & 0.95 & 0.24 \\
\hline $\mathrm{TiO}_{2}$ & 2.62 & 0.15 & 0.08 \\
\hline $\mathrm{Fe}_{2} \mathrm{O}_{3}$ & 10.7 & 27.5 & 0.58 \\
\hline $\mathrm{ZnO}$ & 0.04 & 1.15 & - \\
\hline $\mathrm{ZrO}_{2}$ & 0.09 & - & - \\
\hline $\mathrm{BaO}$ & 0.38 & - & 0.04 \\
\hline $\mathrm{PbO}$ & 0.12 & 0.40 & - \\
\hline $\mathrm{As}_{2} \mathrm{O}_{3}$ & - & 0.35 & - \\
\hline $\mathrm{CuO}$ & 0.05 & 0.44 & - \\
\hline $\mathrm{SO}_{3}$ & 1.36 & 40.6 & 0.03 \\
\hline $\mathrm{Co}_{3} \mathrm{O}_{4}$ & - & 0.04 & - \\
\hline $\mathrm{Cr}_{2} \mathrm{O}_{3}$ & 0.05 & 0.04 & 0.06 \\
\hline $\mathrm{Sb}_{2} \mathrm{O}_{3}$ & - & 0.05 & - \\
\hline $\mathrm{MnO}$ & 0.12 & 0.08 & 0.01 \\
\hline $\mathrm{P}_{2} \mathrm{O}_{5}$ & 0.91 & - & 0.07 \\
\hline $\mathrm{Rb}_{2} \mathrm{O}$ & 0.01 & - & 0.02 \\
\hline L.O.I. & 6.47 & 1.16 & 0.80 \\
\hline
\end{tabular}

The particle size distribution (PSD) of the MT and GS, determined using sieves and sedimentation (for particles below $0.063 \mathrm{~mm}$ ), is presented in Figure 2, which also includes the PSD of the FA, determined by laser granulometry. The fines contents (particles smaller than 63 microns) represented $91 \%, 98 \%$, and $4 \%$ of the MT, FA, and GS compositions, respectively. The density of the MT (32.85 $\left.\mathrm{kN} / \mathrm{m}^{3}\right)$ was significantly higher than those of the GS $\left(25.81 \mathrm{kN} / \mathrm{m}^{3}\right)$ and FA $\left(21.75 \mathrm{kN} / \mathrm{m}^{3}\right)$. The MT showed some plasticity, with a plastic limit of $10.4 \%$ and a liquid limit of $26.3 \%$.

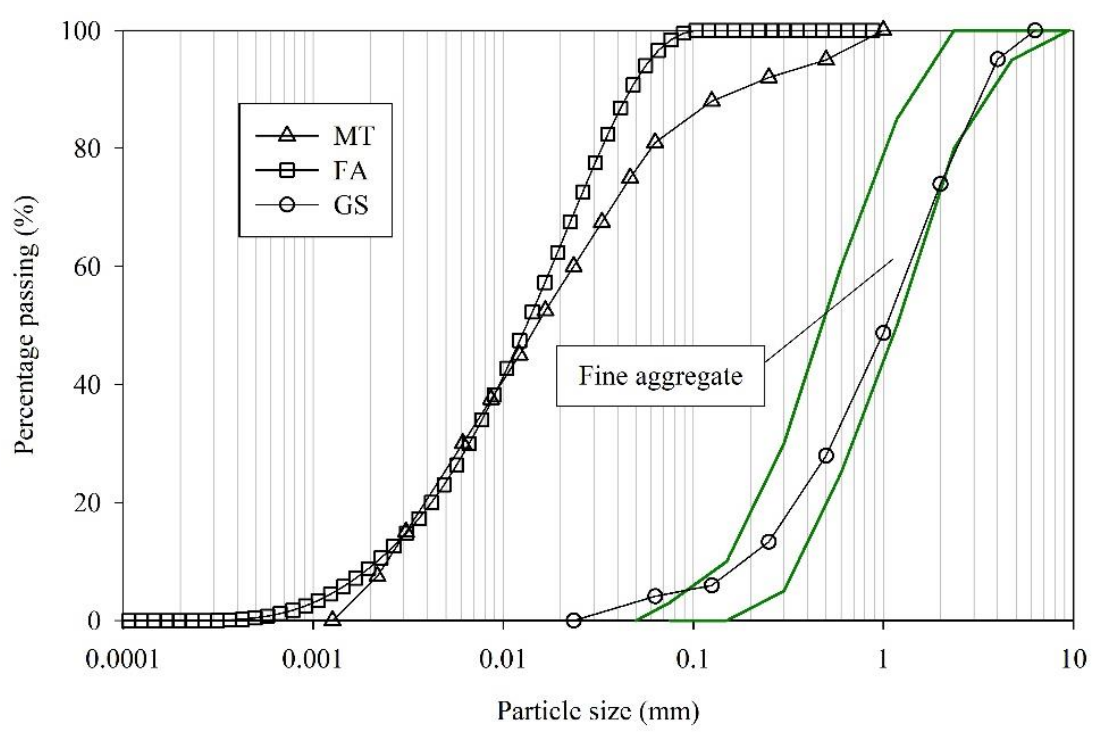

Figure 2. Particle size distribution.

In terms of mineralogy, the $\mathrm{X}$-ray diffraction analysis of the FA showed a main presence of quartz and mullite. The amorphous content of the FA is evidenced by a halo between angles $17^{\circ} 2 \theta$ and $33^{\circ} 2 \theta$. However, the precise quantification of the reactive content in coal fly ash type $\mathrm{F}$ is not straightforward, as demonstrated by Kuenzel and Ranjbar [41], who divided the FA into three different materials: reactive, partially reactive, and inert. They showed that the contribution of the cenospheres (i.e., 
partially reactive fraction) is restricted to the outer layer, which makes it almost impossible to accurately quantify the overall contribution. The diffractogram of the MT revealed, as expected, the presence of pyrite and quartz as the dominant minerals, with some arsenopyrite, muscovite, and chamosite. The GS mostly constitutes quartz.

\subsection{Preparation, Analytical Characterisation, and Mechanical Testing}

The MT was initially dried and submitted to a thorough de-flocculation process, by hand, upon arrival at the laboratory (Figure 3). The FA was received with a water content lower than $3 \%$ and was thus considered ready for use. Preparation of the pastes and mortars started with the dry mixing of the solid components (FA+MT or FA+MT+GS) for 5 min in a Hobart counter mixer.

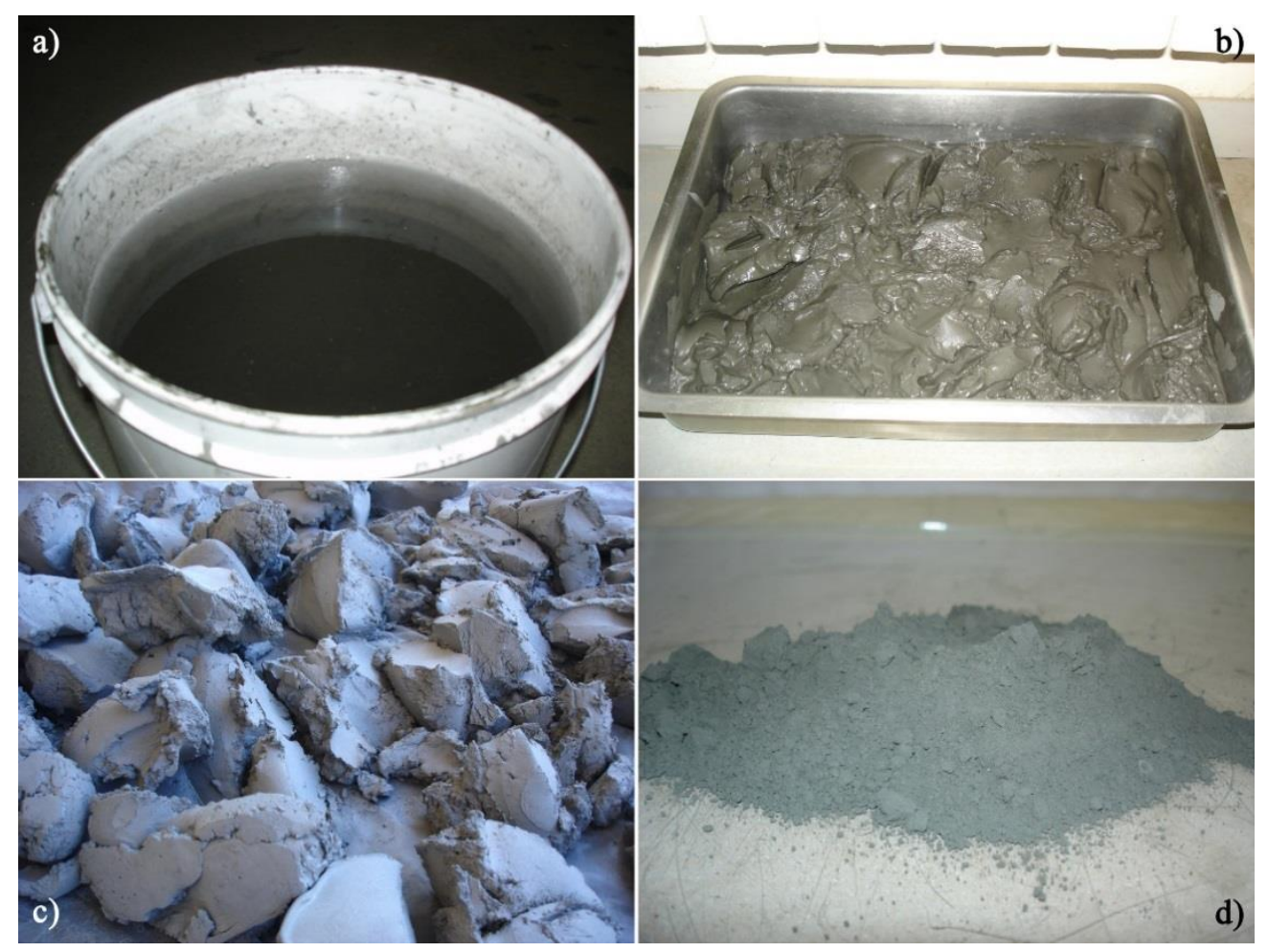

Figure 3. Tailings as received in the laboratory (a); after most of the water was removed (b); after drying in the oven (c); after breaking the clods (d).

The activator was a combination of sodium hydroxide (SH) and sodium silicate (SS), with different $\mathrm{SS} / \mathrm{SH}$ weight ratios of $0.5,0.75,1.00$, and 1.25 (Table 2). The sodium hydroxide was supplied in pellets, with a specific gravity of 2.13 at $20^{\circ} \mathrm{C}(99 \mathrm{wt} . \%)$, and was then dissolved in deionised water to previously defined concentrations of 7.5, 10.0,12.5, and 15.0 molal. The SS presented a unit weight of $1.464 \mathrm{~g} / \mathrm{cm}^{3}, \mathrm{a} \mathrm{SiO}_{2} / \mathrm{Na}_{2} \mathrm{O}$ weight ratio of 2.0 (molar oxide ratio of 2.063), and a $\mathrm{Na}_{2} \mathrm{O}$ concentration in the solution of $13.0 \%$. Four to six hours after mixing the SH and the SS, when the temperature of the resulting activator reached $20^{\circ} \mathrm{C} \pm 2{ }^{\circ} \mathrm{C}$, it was mixed with the solid components, and additional mixing followed to guarantee homogenisation.

A crucial aspect of the preparation of the pastes was the definition of their optimal compaction properties, namely, the dry unit weight and its equivalent water content, which was achieved through a standard Proctor test. This Proctor test was performed on the paste with $20 \%$ FA and $80 \%$ MT and on the mortar with 20\% FA, 30\% MT, and 50\% GS. A dry unit weight of $\gamma_{\mathrm{d}}=1.974 \mathrm{~g} / \mathrm{cm}^{3}$ and a corresponding water content of $\omega=13.0 \%$ were obtained for the paste, while values of $\gamma_{d}=2.064$ $\mathrm{g} / \mathrm{cm}^{3}$ and $\omega=9.0 \%$ were obtained for the mortar. The compositions of the pastes and mortars tested 
are presented in Tables 2 and 3, respectively. Note that the slight variations in the FA/MT ratios in groups $\mathrm{P} 2$ and $\mathrm{P} 3$ were necessary to maintain the activator/ash ratio (Ac/FA) at a constant value of 0.75 .

Table 2. Identification and nominal characterization of the pastes FA = fly ash; $\mathrm{MT}=$ mine tailings; $\mathrm{SH}$ = sodium hydroxide; $\mathrm{SS}=$ sodium silicate).

\begin{tabular}{|c|c|c|c|c|c|c|c|c|c|c|c|}
\hline \multirow[b]{2}{*}{ Paste } & \multicolumn{3}{|c|}{ FA+MT (Sol) } & \multicolumn{6}{|c|}{ Activator (Ac) } & \multicolumn{2}{|c|}{ Weight Ratios } \\
\hline & $\begin{array}{c}\text { FA } \\
\text { (wt.\%) }\end{array}$ & $\begin{array}{c}\text { MT } \\
\text { (wt.\%) }\end{array}$ & $\begin{array}{c}\text { FA/MT } \\
\text { (wt.) }\end{array}$ & $\begin{array}{l}\text { SH conc. } \\
\text { (molal) }\end{array}$ & $\begin{array}{c}\text { SS/SH } \\
\left({ }^{*}\right)\end{array}$ & $\underset{(* *)}{\mathrm{Na}_{2} \mathrm{O}}$ & $\begin{array}{c}\mathrm{SiO}_{2} \\
(* *)\end{array}$ & $\mathrm{Na}_{2} \mathrm{O} / \mathrm{SiO}_{2}$ & $\begin{array}{c}\mathrm{H}_{2} \mathrm{O} \\
(* *)(* * *)\end{array}$ & Ac/FA & Ac/Sol \\
\hline P0 & - & 100 & - & 12.5 & 0.00 & $25.8 \%$ & $0.0 \%$ & - & $66.7 \%$ & - & 0.188 \\
\hline PRef & 25 & 75 & 0.333 & 7.5 & 0.50 & $16.4 \%$ & $4.5 \%$ & 3.65 & $71.3 \%$ & 0.75 & 0.189 \\
\hline P1A & 29 & 71 & 0.408 & 7.5 & 0.50 & $16.4 \%$ & $4.5 \%$ & 3.65 & $71.3 \%$ & 0.65 & 0.187 \\
\hline P1B & 22 & 78 & 0.282 & 7.5 & 0.50 & $16.4 \%$ & $4.5 \%$ & 3.65 & $71.3 \%$ & 0.85 & 0.190 \\
\hline $\mathrm{P} 1 \mathrm{C}$ & 20 & 80 & 0.250 & 7.5 & 0.50 & $16.4 \%$ & $4.5 \%$ & 3.65 & $71.3 \%$ & 0.95 & 0.195 \\
\hline P2A & 26 & 74 & 0.351 & 10.0 & 0.50 & $19.3 \%$ & $4.5 \%$ & 4.28 & $67.6 \%$ & 0.75 & 0.195 \\
\hline P2B & 28 & 72 & 0.389 & 12.5 & 0.50 & $21.7 \%$ & $4.5 \%$ & 4.83 & $64.4 \%$ & 0.75 & 0.210 \\
\hline $\mathrm{P} 2 \mathrm{C}$ & 29 & 71 & 0.408 & 15.0 & 0.50 & $23.9 \%$ & $4.5 \%$ & 5.30 & $61.7 \%$ & 0.75 & 0.218 \\
\hline P3A & 25 & 75 & 0.333 & 7.5 & 0.75 & $16.0 \%$ & $5.8 \%$ & 2.77 & $69.7 \%$ & 0.75 & 0.188 \\
\hline P3B & 26 & 74 & 0.351 & 7.5 & 1.00 & $15.7 \%$ & $6.8 \%$ & 2.32 & $68.5 \%$ & 0.75 & 0.195 \\
\hline P3C & 26 & 74 & 0.351 & 7.5 & 1.25 & $15.4 \%$ & $7.5 \%$ & 2.06 & $67.5 \%$ & 0.75 & 0.195 \\
\hline
\end{tabular}

$\left({ }^{*}\right)$ Solution weight ratio; $\left({ }^{* *}\right)$ Weight percentage of the total activator added; $\left({ }^{* * *}\right)$ Used to achieve $\mathrm{NaOH}$ with the predetermined concentration.

Table 3. Identification and nominal characterization of the mortars (FA = fly ash; $\mathrm{MT}=$ mine tailings; GS = soil; Ac $=$ activator).

\begin{tabular}{|c|c|c|c|c|}
\hline \multirow{2}{*}{ Mortar } & \multicolumn{2}{|c|}{$\mathrm{FA}+\mathrm{MT}+\mathrm{GS}\left(\mathrm{Sol}_{2}\right)$} & \multicolumn{2}{|c|}{ Weight Ratios } \\
\hline & FA/MT (wt.) & GS content & Ac/FA $\left(^{*}\right)$ & $\mathrm{Ac} / \mathrm{Sol}_{2}$ \\
\hline MRef & 0.33 & \multirow{10}{*}{$50 \%$} & 0.78 & 0.130 \\
\hline M1A & 0.40 & & 0.68 & 0.131 \\
\hline M1B & 0.28 & & 0.88 & 0.129 \\
\hline M1C & 0.25 & & 0.99 & 0.132 \\
\hline M2A & 0.35 & & 0.78 & 0.135 \\
\hline M2B & 0.39 & & 0.78 & 0.145 \\
\hline M2C & 0.40 & & 0.78 & 0.151 \\
\hline M3A & 0.33 & & 0.78 & 0.130 \\
\hline M3B & 0.35 & & 0.78 & 0.135 \\
\hline M3C & 0.35 & & 0.78 & 0.135 \\
\hline
\end{tabular}

Each mixture was statically compacted inside a cylindrical mould $37 \mathrm{~mm}$ in diameter and with a height of $70 \mathrm{~mm}$ (EN 13286-53 [42]). After demoulding, they were stored under $85^{\circ} \mathrm{C}$ and $20 \%$ relative humidity and tested after $24 \mathrm{~h}$. The uniaxial compressive strengh (UCS) tests were carried out under monotonic displacement control at a rate of $0.2 \mathrm{~mm} / \mathrm{min}$. The results represent the average of three tested specimens.

The original FA and MT, as well as selected pastes, were characterised using scanning electron microscopy (SEM), X-ray diffraction (XRD), and Fourier transform infrared spectroscopy (FTIR). The FA and MT were also submitted to thermogravimetric analysis (TGA) by exposure to gradually increasing temperatures.

\subsection{Leaching Tests}

Two leaching test procedures were performed. The first, designated "LTT1", was based on standard EN 12457-4 [43]. It was performed on a specimen made from paste P2B. The fabrication and curing procedures were identical to the UCS. The element concentration on the eluate was determined following EN 16192 [44], and the values obtained were compared with the limits imposed by Council Decision 2003/33/EC [45]. 
The second test, designated "LTT2", was developed to study the leachability over time. After curing, the P2B specimen was submerged in distilled water, observing a liquid/solid weight ratio of 10:1. Two leachate samples of $50 \mathrm{~mL}$ each were then collected after $3,7,14$, and 28 days. The $\mathrm{pH}$ was measured before the sampling. The values presented are the average of two replicates. Additionally, the soluble $\mathrm{SO}_{3}$ content present in the water from the ponds, collected from the MT sample immediately upon arrival at the laboratory, was also measured. Finally, dry samples of MT and FA were left submerged in distilled water for 28 days, in separate containers, and their soluble $\mathrm{SO}_{3}$ was also measured. The electrical conductivity of the four samples of water (i.e., from the pond, after submersion of original MT and FA for 28 days, and after submersion of a P2B monolith for 28 days) was also measured.

\section{Results}

\subsection{UCS}

The MT was initially activated with a 12.5 molal sodium hydroxide solution, without FA (paste P0, Table 2), in order to assess the reactivity of the tailings. It immediately became clear, based on the structural integrity of these specimens, that chemical reactions did occur and generated some type of binding gel. This was confirmed by the UCS value of $1.8 \mathrm{MPa}$ obtained. A parametric analysis was then developed to evaluate the influence of different parameters on compressive strength, namely, the ash/tailings weight ratio (FA/MT), the sodium hydroxide concentration (SH conc.), and the silicate/hydroxide weight ratio (SS/SH).

Regarding the ash/tailings ratio (with constant $\mathrm{NaOH}$ concentration and SS/SH ratio of 7.5 molal and 0.5, respectively), the results presented in Figure 4 show that an increase in the ash content produced an increase in compressive strength (UCS). The exception to this general trend was the paste with the lowest FA/MT ratio. This is not surprising, given that with a reduction in fly ash, the UCS tends to stabilise. Other authors [18], when studying the simultaneous activation of tungsten mining mud and red clay brick waste (precursor), using an activator solution based on SS and SH, obtained a compressive strength for the blends with a precursor content of $50 \%$ that was 3 times higher than that for the blends with only $10 \%$. These authors were also able to prove that an increase in precursor content promoted the dissolution of some phases of the tungsten MT, with a positive effect on strength development. Given its higher strength among the P1 set, paste P1A was chosen for further analyses. The addition of the sandy aggregate to the paste produced a clearly positive influence on the mechanical response for every FA/MT ratio, representing a strength increase of between $14 \%$ (lowest FA/MT ratio of 0.25$)$ and $42 \%(\mathrm{FA} / \mathrm{MT}=0.33)$.

Regarding the influence of the $\mathrm{NaOH}$ concentration (Figure 5), it became apparent that this variable was responsible for the most significant impact on UCS. An increase in concentration was responsible for an increase in UCS by favouring alkalinity levels which facilitate the dissolution of the species needed to form the final structural matrix. Cihangir et al. [16], when investigating the effect of the activator composition on the strength of high-sulphide tailings, obtained UCS values very similar to those here presented (between 1 and $2 \mathrm{MPa}$ after 28 days, and between 2.5 and $4.0 \mathrm{MPa}$ after 1 year). These authors also tested the use of Portland cement, which resulted in a compressive strength of $1.5 \mathrm{MPa}$ after one year of curing. Moukannaa et al. [17], also focusing on $\mathrm{NaOH}$ properties for the activation of phosphate MT and metakaolin blends, reached a similar conclusion, i.e., an increase in $\mathrm{NaOH}$ concentration produces denser and stronger pastes. Although paste P2C reached the highest UCS among the P2 set, paste P2B was chosen for further analyses since its strength/cost compromise was considered more effective, i.e., the strength showed by paste P2B is enough for situations where this material might be used (e.g., structural embankments, pavement bases and sub-bases), and its cost is approximately $90 \%$ that of P2C. The influence of the aggregate phase on UCS was also positive. However, it is noticeable that the strength increase due to the addition of sand was more significant 
than that registered when analysing the FA/MT ratio, varying between $42 \%$ (lowest concentration of 7.5 molal $)$ and $75 \%$ (12.5 molal).

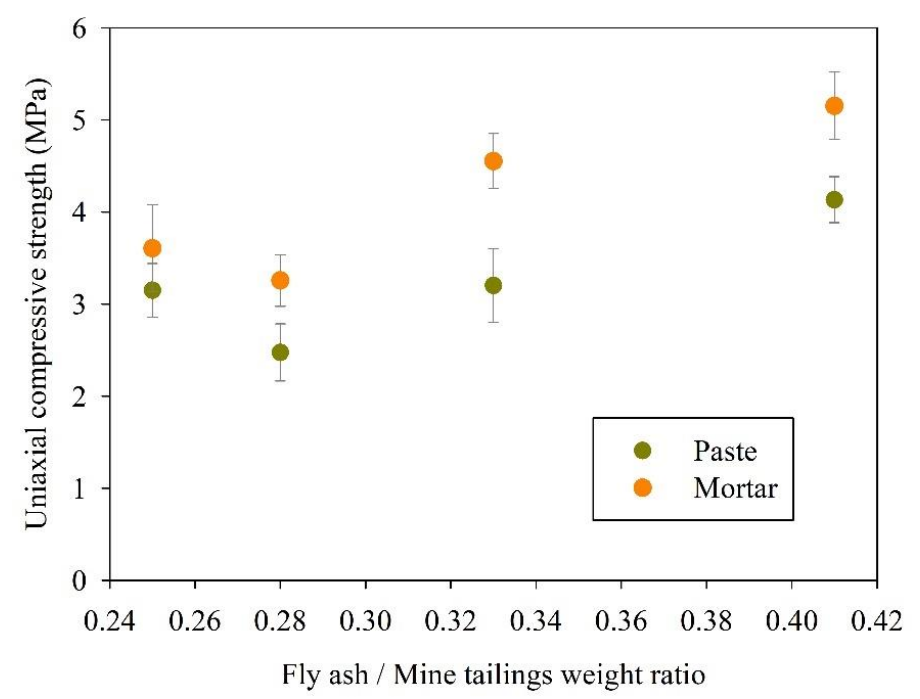

Figure 4. Influence of the ash/tailings weight ratio on compressive strength.

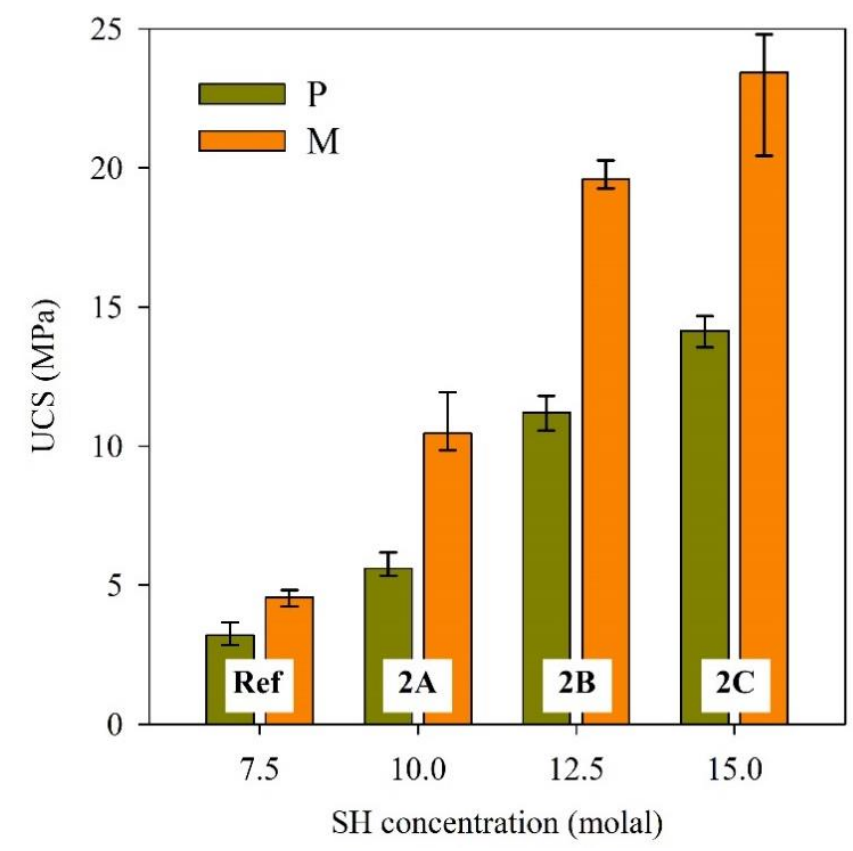

Figure 5. Influence of the sodium hydroxide concentration on compressive strength.

Of the three factors considered, the SS/SH weight ratio appears to be the factor producing the lowest level of influence on strength development (Figure 6). Even though this analysis is not straightforward, since there are other variables changing besides the $\mathrm{SS} / \mathrm{SH}$ (i.e., the $\mathrm{Ac} / \mathrm{Sol}$ and $\mathrm{Na}_{2} \mathrm{O} / \mathrm{SiO}_{2}$ ratios and the water content), the results clearly show that a decrease in the SS/SH ratio did not produce a decrease in UCS. This also suggests that the sodium silicate content might be even further reduced without hindering the mechanical performance, which would represent a significant cost reduction or, possibly, a decrease in logistic complexity during live-scale applications if the SS is eliminated. Similar to the previous two analyses, the addition of the sandy skeleton showed a positive effect on UCS. Also similar is the fact that the trend of the UCS values obtained with the aggregate was very close to the trend obtained without it. In this case, the strength increase varied between $37 \%(\mathrm{SS} / \mathrm{SH}=0.75)$ and $72 \%$ $(\mathrm{SS} / \mathrm{SH}=1.0)$. 


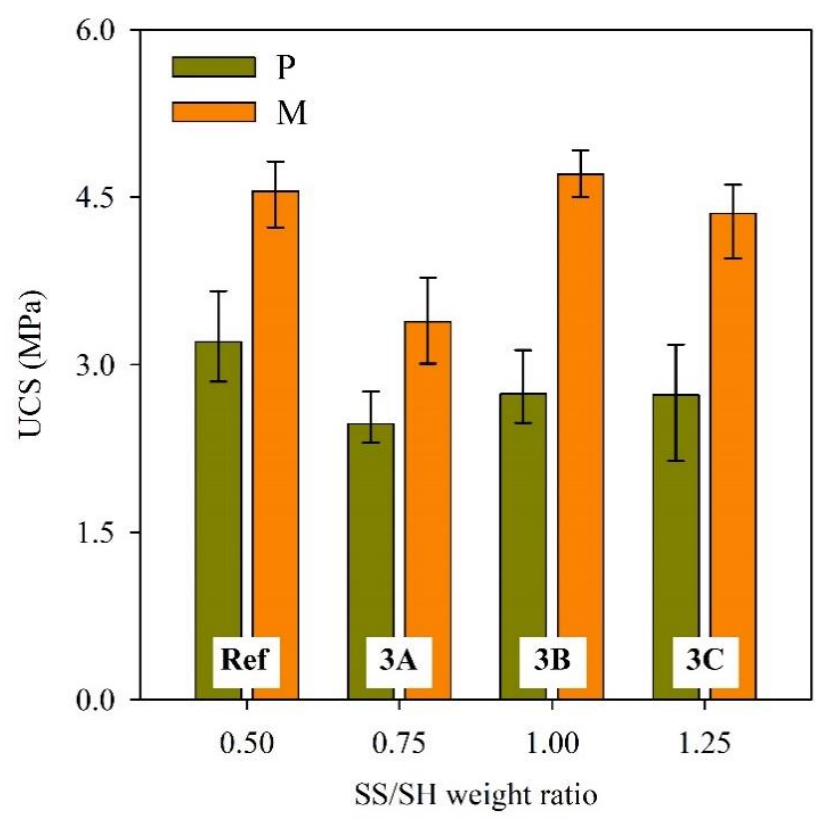

Figure 6. Influence of the silicate/hydroxide weight ratio on compressive strength.

\subsection{Thermogravimetric Analysis}

Figure 7 shows the results of the thermogravimetric analysis (TGA) and respective derivative (DTG) of the tailings in the range $75{ }^{\circ} \mathrm{C}$ to $825^{\circ} \mathrm{C}$. The analysis of the fly ash is also included for comparison purposes. According to the literature [46], approximately $0.5 \%$ of the total weight loss usually registered during thermogravimetry of coal fly ash occurs below $500{ }^{\circ} \mathrm{C}$, with an additional $2 \%$ after that, corresponding to the release of volatile matter from the sample and assuming that the TGA is carried in an oxidizing atmosphere (e.g., air) [47]. This behaviour is consistent with the result obtained for this particular FA. The MT started a significant weight decrease at the $375^{\circ} \mathrm{C}$ mark, of more than $10 \%$, resulting from the transformation of the pyrite's sulphur into gas [48]. When the temperature reached $585^{\circ} \mathrm{C}$, another stepped loss was noticeable, related with further decomposition of the pyrite [49].

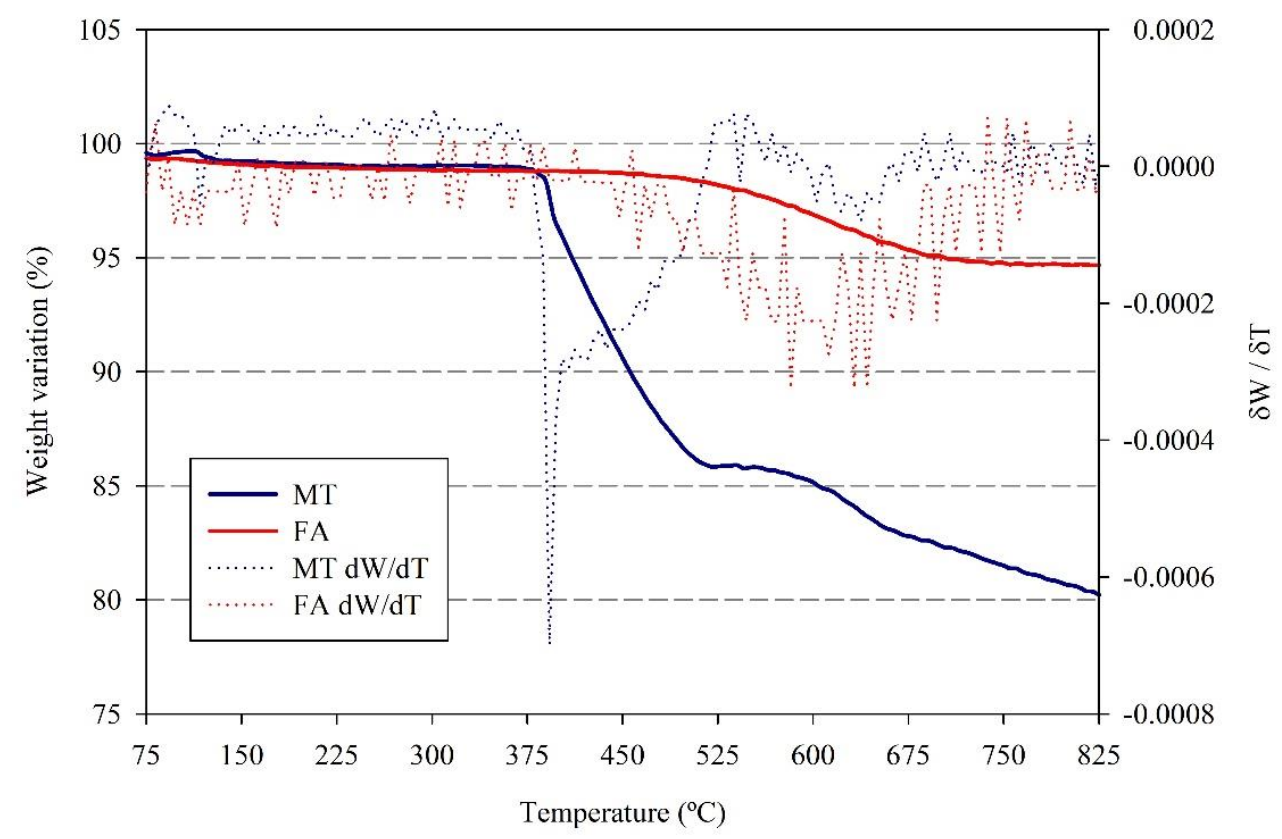

Figure 7. Thermogravimetry and derivative thermogravimetry of the original FA and MT. 


\subsection{Mineralogical and Microstructural Characterization}

Figure 8 shows the XRD diffractograms of selected pastes and anhydride FA and MT. Based on the size of the humps in the FA and MT diffractograms, associated with their amorphous content, it appears that the MT has a higher crystalline content than the FA.

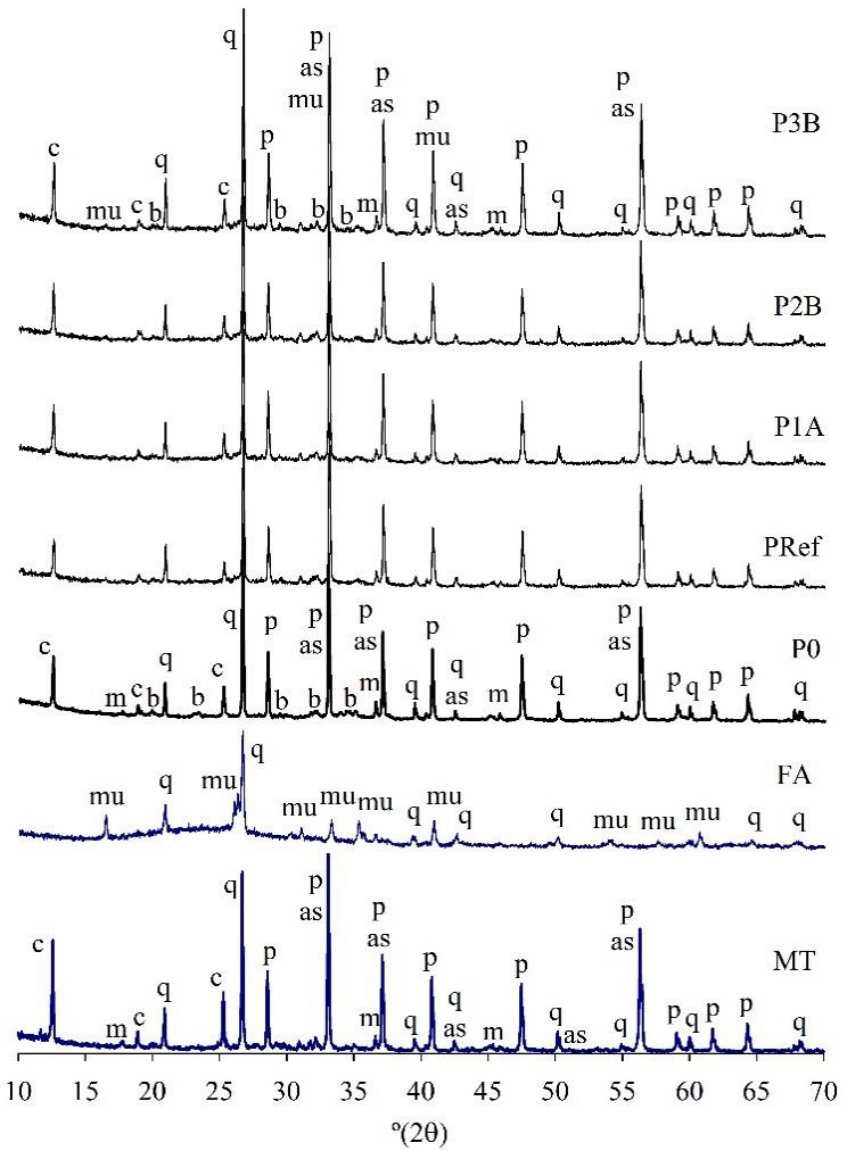

Figure 8. Diffractograms of the tailings, fly ash, and selected pastes (as, arsenopyrite: FeAsS; $b$, burkeite: $\mathrm{Na}_{6}\left(\mathrm{CO}_{3}\right)\left(\mathrm{SO}_{4}\right) 2$; c, chamosite: $\left(\mathrm{Fe}^{2+} ; \mathrm{Mg}^{2} \mathrm{Fe}^{3+}\right)_{5} \mathrm{Al}\left(\mathrm{Si}_{3} \mathrm{Al}\right) \mathrm{O}_{10}(\mathrm{OH} ; \mathrm{O})_{8} ; \mathrm{mu}$, mullite: $\mathrm{Al}_{6} \mathrm{Si}_{2} \mathrm{O}_{13} ; \mathrm{m}$, muscovite: $\mathrm{KAl}_{3} \mathrm{SiO}_{10}(\mathrm{OH})_{2}$; p, pyrite: $\mathrm{FeS}_{2} ;$ q, quartz: $\left.\mathrm{SiO}_{2}\right)$.

The pastes showed peaks associated with the crystalline phases of the FA (quartz and mullite) and MT (arsenopyrite, chamosite, muscovite, quartz, and pyrite), only with a lower intensity due to a dilution effect. This indicates that such phases are mostly inert. Some of the peaks associated with the chamosite phase $\left(\mathrm{Fe}^{2+} ; \mathrm{Mg} ; \mathrm{Fe}^{3+}\right)_{5} \mathrm{Al}\left(\mathrm{Si}_{3} \mathrm{Al}\right) \mathrm{O}_{10}(\mathrm{OH} ; \mathrm{O})_{8}$ on the MT showed lower intensities after activation (paste $\mathrm{P} 0$ ), suggesting that these phases partially participated in the reactions. This intensity reduction appears to have also occurred on the remaining four pastes analysed; however, in this case, the original MT peaks are diluted with the FA peaks.

The only new phase that was found to develop in the activated MT (paste P0) was burkeite $\left(\mathrm{Na}_{6}\left(\mathrm{CO}_{3}\right)\left(\mathrm{SO}_{4}\right)_{2}\right)$, which is basically a sodium sulphate carbonate. Although the burkeite peaks were less intense when FA was added to the precursor combination, this mineralogical phase was still visible, suggesting that the released $S$ ions combined with the sodium, forming sodium sulphate.

The FTIR spectra of the same pastes are presented in Figure 9. The FA presents two main bands, at $1010 \mathrm{~cm}^{-1}$ (Si-O-T stretching vibrations, with $\mathrm{T}=\mathrm{Si}$ or $\mathrm{Al}$ ) and $410 \mathrm{~cm}^{-1}$ (O-Si-O). The MT shows a classic and very intense Si-O-T band at around $980 \mathrm{~cm}^{-1}$, corresponding to asymmetric stretching modes of the $\mathrm{SiO}_{4}$ and $\mathrm{AlO}_{4}$ tetrahedra; this band was maintained in the pastes. The bands at 872 $\mathrm{cm}^{-1}$ and $773 \mathrm{~cm}^{-1}$ (also on the FA), typical of Si-O-T ( $\mathrm{T}=\mathrm{Si}$ or $\mathrm{Al}$ ) stretching vibrations, and the band 
at $690 \mathrm{~cm}^{-1}$ (also in the FA), typical of Al-O, appear on the original MT and in the all the resulting pastes, which reflects the partial crystalline nature of the MT.

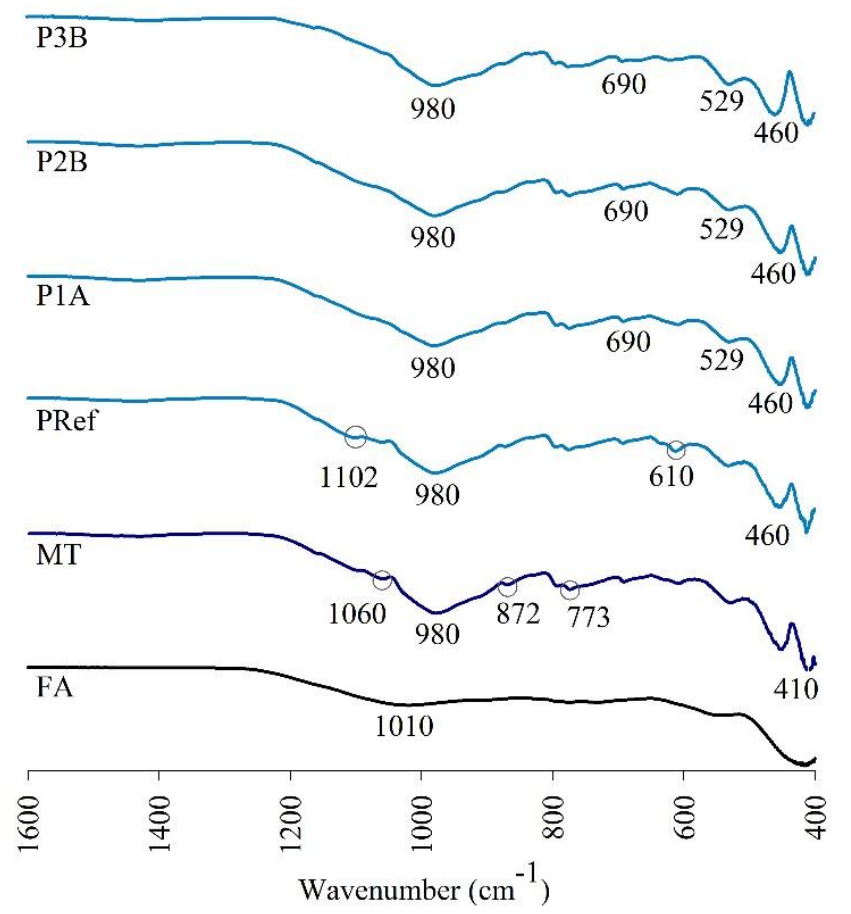

Figure 9. IR spectra of the original materials and most effective pastes.

The FA band at around $1010 \mathrm{~cm}^{-1}$ was partially dissolved in the reactions, indicating the presence of soluble material, while the peak at $410 \mathrm{~cm}^{-1}$ was maintained or partially dissolved (it is difficult to interpret since it is overlapping with an intense peak from the MT).

Regarding the MT, the original peak at $1060 \mathrm{~cm}^{-1}$, associated with $\mathrm{Si}-\mathrm{O}$ or Al-O, was still present in paste PRef, but not in the remaining three pastes, suggesting that parts of the silicon and aluminium species dissolved from the MT were able to form new compounds. The intensity of the $872 \mathrm{~cm}^{-1}$ peak (MT) was maintained in PRef, but showed a slight decrease in P1A, P2B, and P3B, suggesting that some Si-O-T links were broken. A similar situation was found at $1102 \mathrm{~cm}^{-1}$ (typical of S-O asymmetric stretching vibrations in $\mathrm{SO}_{4}$ tetrahedra), i.e., it was still present in the PRef paste but was eliminated in the remaining pastes, suggesting the presence of soluble sulphur species. The intensity of the peak at $610 \mathrm{~cm}^{-1}$, representing O-S-O deformation vibrations in $\mathrm{SO}_{4}$, increased for pastes PRef and P2B, suggesting the formation of new molecules involving dissolved $\mathrm{S}$, and slightly decreased for pastes P1A and P3B relative to the original MT. Bands at 529, 460, and $410 \mathrm{~cm}^{-1}$ (MT), indicating O-Si-O vibrations, were also found in the pastes, with similar intensities. A brief summary of the bands involving sulphur is presented in Table 4.

Table 4. Summary of the sulphur-related peaks presented in Figure 9.

\begin{tabular}{|c|c|c|c|}
\hline Band & Bond & Type & Comment \\
\hline $1102\left(\mathrm{~cm}^{-1}\right)$ & $\mathrm{S}-\mathrm{O}$ & $v_{\mathrm{as}}$ & $\begin{array}{c}\text { Showed some traces of the original MT peak in the PRef paste, } \\
\text { and disappeared in the remaining pastes }\end{array}$ \\
\hline $610\left(\mathrm{~cm}^{-1}\right)$ & $\mathrm{O}-\mathrm{S}-\mathrm{O}$ & $\delta$ & Increased (decreased) intensity in pastes PRef, P2B (P1A, P3B) \\
\hline
\end{tabular}

SEM and EDX of P0, PRef, P1A, P2B, and P3B are presented in Figures 10 and 11, respectively. The presence of Fe in the $\mathrm{P} 0$ is, as expected, very intense. The gel phase, characterised in Figure 10, essentially constituted $\mathrm{Na}, \mathrm{Al}, \mathrm{Si}$, and $\mathrm{S}$. Based on these semi-quantitative values, it is possible to 
conclude that a N-A-S-H-type gel was developed, responsible for the strength gain. However, at this stage, the possible inclusion of sulphur ions in the gel structure was also considered, even if the exact role of such ions was not yet established.

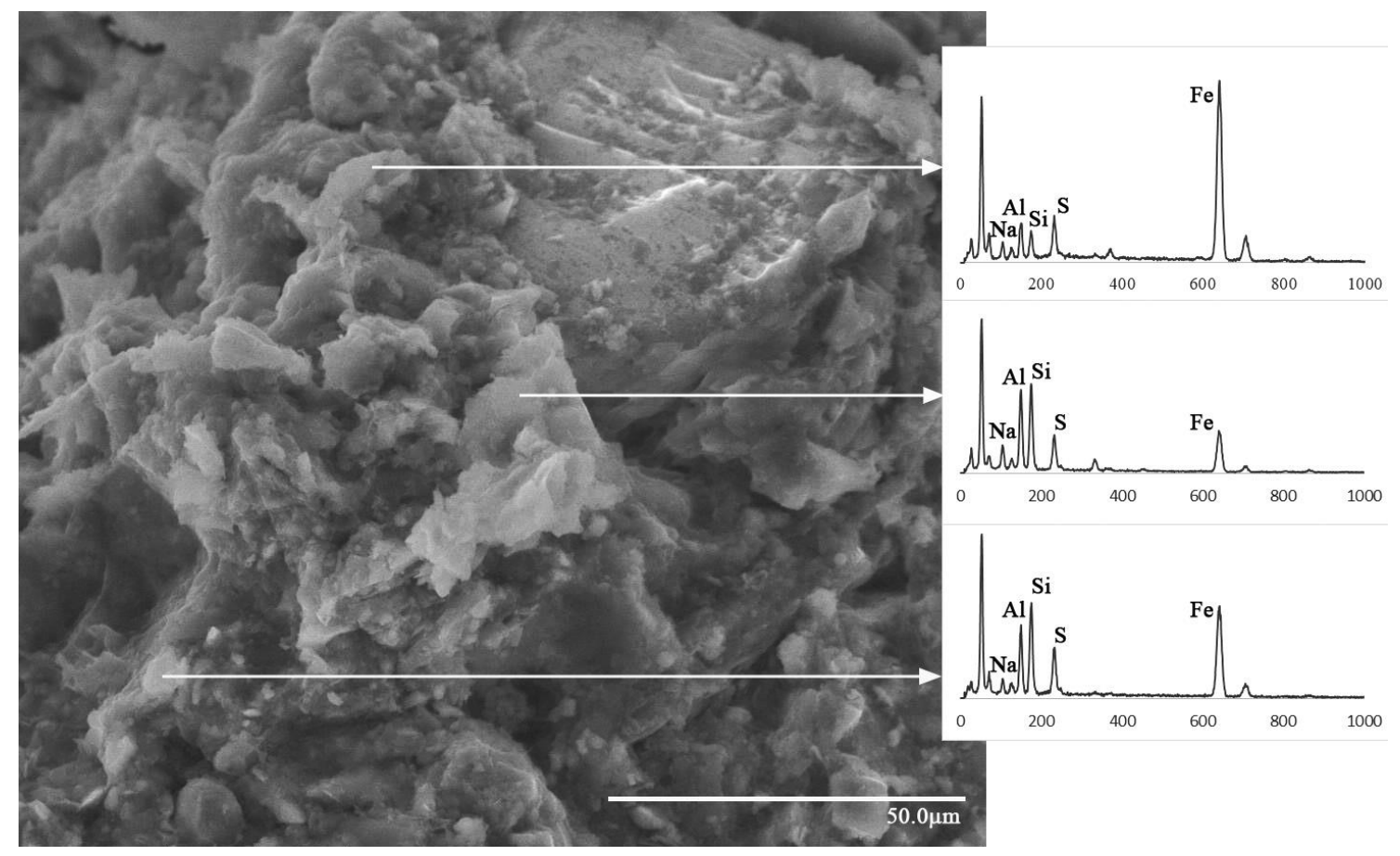

Figure 10. SEM micrographs and EDX analysis of paste P0.

Table 5. Characterisation of the points presented in Figure 11.

\begin{tabular}{|c|c|c|c|c|c|c|c|c|}
\hline \multirow{2}{*}{ Paste } & \multirow{2}{*}{ Point } & \multicolumn{4}{|c|}{ Element Content (wt.\%) } & \multicolumn{3}{|c|}{ Molar Ratios } \\
\hline & & Si & Al & $\mathrm{Na}$ & S & $\mathrm{SiO}_{2} / \mathrm{Al}_{2} \mathrm{O}_{3}$ & $\mathrm{Na}_{2} \mathrm{O} / \mathrm{Al}_{2} \mathrm{O}_{3}$ & $\mathrm{Na}_{2} \mathrm{O} / \mathrm{SO}_{3}$ \\
\hline \multirow[t]{4}{*}{ PRef } & A1 & 17 & 16 & 8 & 6 & 2.161 & 0.560 & 0.957 \\
\hline & A2 & 21 & 21 & 4 & 2 & 2.093 & 0.248 & 1.405 \\
\hline & A3 & 21 & 20 & 4 & 3 & 2.155 & 0.262 & 1.155 \\
\hline & A4 & 22 & 21 & 2 & 1 & 2.133 & 0.105 & 2.031 \\
\hline \multirow[t]{4}{*}{ P1A } & B1 & 20 & 19 & 3 & 3 & 2.213 & 0.206 & 0.711 \\
\hline & B2 & 18 & 18 & 5 & 5 & 2.067 & 0.339 & 0.706 \\
\hline & B3 & 16 & 17 & 4 & 6 & 1.950 & 0.269 & 0.449 \\
\hline & B4 & 11 & 12 & 4 & 7 & 1.936 & 0.423 & 0.440 \\
\hline \multirow[t]{6}{*}{$\mathrm{P} 2 \mathrm{~B}$} & $\mathrm{C} 1$ & 3 & 3 & 35 & 31 & 1.837 & 13.565 & 0.803 \\
\hline & $\mathrm{C} 2$ & 7 & 6 & $30\left(^{*}\right)$ & $18\left(^{*}\right)$ & 2.483 & 5.790 & 1.204 \\
\hline & C3 & 3 & 2 & $\left.31{ }^{*}\right)$ & $37\left(^{*}\right)$ & 3.576 & 17.874 & 0.572 \\
\hline & $\mathrm{C} 4$ & 18 & 25 & 5 & 3 & 1.497 & 0.258 & 1.161 \\
\hline & $\mathrm{C} 5$ & 1 & 1 & $41\left(^{*}\right)$ & $40\left(^{*}\right)$ & 1.931 & 73.893 & 0.708 \\
\hline & C6 & 38 & 2 & 5 & 3 & 38.087 & 2.650 & 1.155 \\
\hline \multirow[t]{4}{*}{ P3B } & D1 & 15 & 13 & 7 & 3 & 2.319 & 0.585 & 1.642 \\
\hline & D2 & 23 & 17 & 5 & 2 & 2.832 & 0.348 & 1.900 \\
\hline & D3 & 15 & 16 & 4 & 3 & 1.937 & 0.331 & 1.009 \\
\hline & D4 & 19 & 14 & 4 & 9 & 2.691 & 0.314 & 0.293 \\
\hline
\end{tabular}

$\left(^{*}\right)$ sodium sulphate, which originated from burkeite.

In terms of morphology, the micrographs indicate fairly compacted material due to the formation of gel with a $\mathrm{SiO}_{2} / \mathrm{Al}_{2} \mathrm{O}_{3}$ molar ratio of approximately 2 (Table 5). Nevertheless, several intact pyrite and ash particles are still visible. The P2B paste presented an apparent lower amount of unreacted FA particles (Figure 11c) and a higher volume of gel compared with the remaining three pastes. This higher reaction degree, responsible for the highest UCS reached by this paste (Figure 5), is a consequence of the higher concentration of the activating solution (12.5 M, Table 2). 


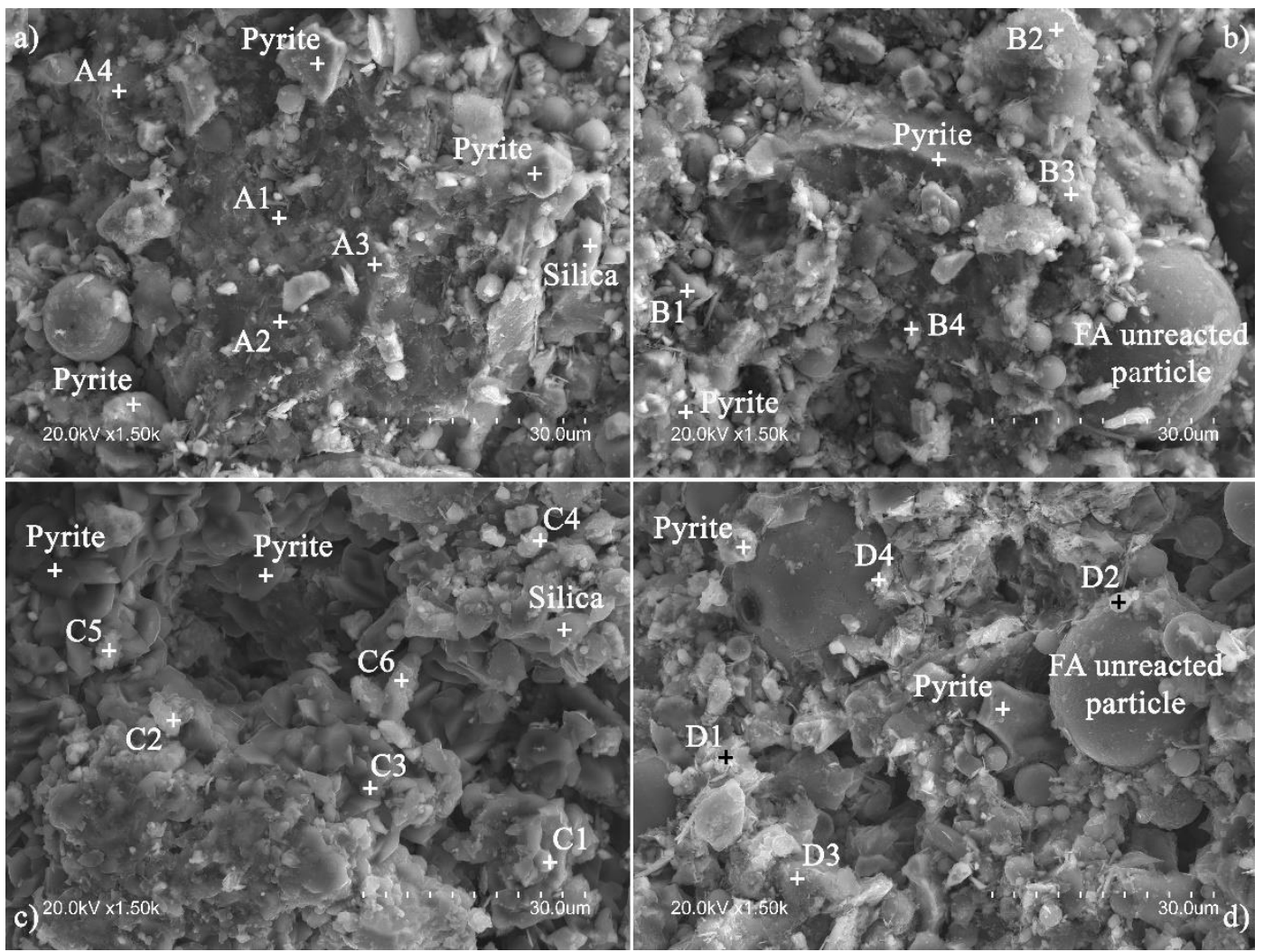

Figure 11. SEM micrographs and EDX analysis of pastes Pref (a), P1A (b), P2B (c), and P3B (d) (EDX data summarised in Table 5).

Based on the gel composition, assessed from a total of 120 EDX points from which a representative sample was selected and presented in Figure 11 (with corresponding data summarised in Table 5), a typical N-A-S-H gel was formed, although with significant percentages of sulphur included. The presence of sulphur in the gel indicates that this element had some influence on the composition of the gel structure, probably encapsulated in the aluminosilicate matrix [50]. The high sulphur percentages found in paste $\mathrm{P} 2 \mathrm{~B}$ were always associated with high sodium contents, indicating the possible development of sodium sulphate, which was found in the mineral form of burkeite (Figure 8). The majority of the gel points from the remaining three pastes presented a significantly higher content of $\mathrm{Si}+\mathrm{Al}$ than $\mathrm{Na}+\mathrm{S}$, meaning that the formation of sodium sulphate was less intense in these pastes.

\subsection{Environmental Performance}

Based on the results already presented, namely, the mechanical performance and the activator content used, paste P2B was determined to be the most adequate to study the potential of the technique to fix the contaminants present in the MT. This study was based on the use of two different methodologies (LTT1 and LTT2) to obtain an eluate solution from the solid pastes. Three different materials were submitted to the LTT1 test, namely, the original MT without any addition, the activated MT (P0), and the MT+FA paste designated P2B. Only the latter was submitted to LTT2.

The leachable concentrations obtained during test LTT1 were compared with the threshold values presented in Council Decision 2003/33/EC for inert waste, non-hazardous waste, and hazardous waste (Figure 12). In general, activation of the original MT (paste P0) produced a decrease in the leached concentration, the exceptions being As, which showed a significant increase after the AA reactions, and chlorides and sulphates. The eluate collected from paste P2B improved upon the performance showed by the $\mathrm{P} 0$ paste, although elements $\mathrm{Cr}$ and $\mathrm{Pb}$ presented slightly higher solubility, above even the values presented by the original MT. Nevertheless, the addition of FA resulted in increased 
performance and complied with the most severe limits imposed by the European standard (inert waste disposal).

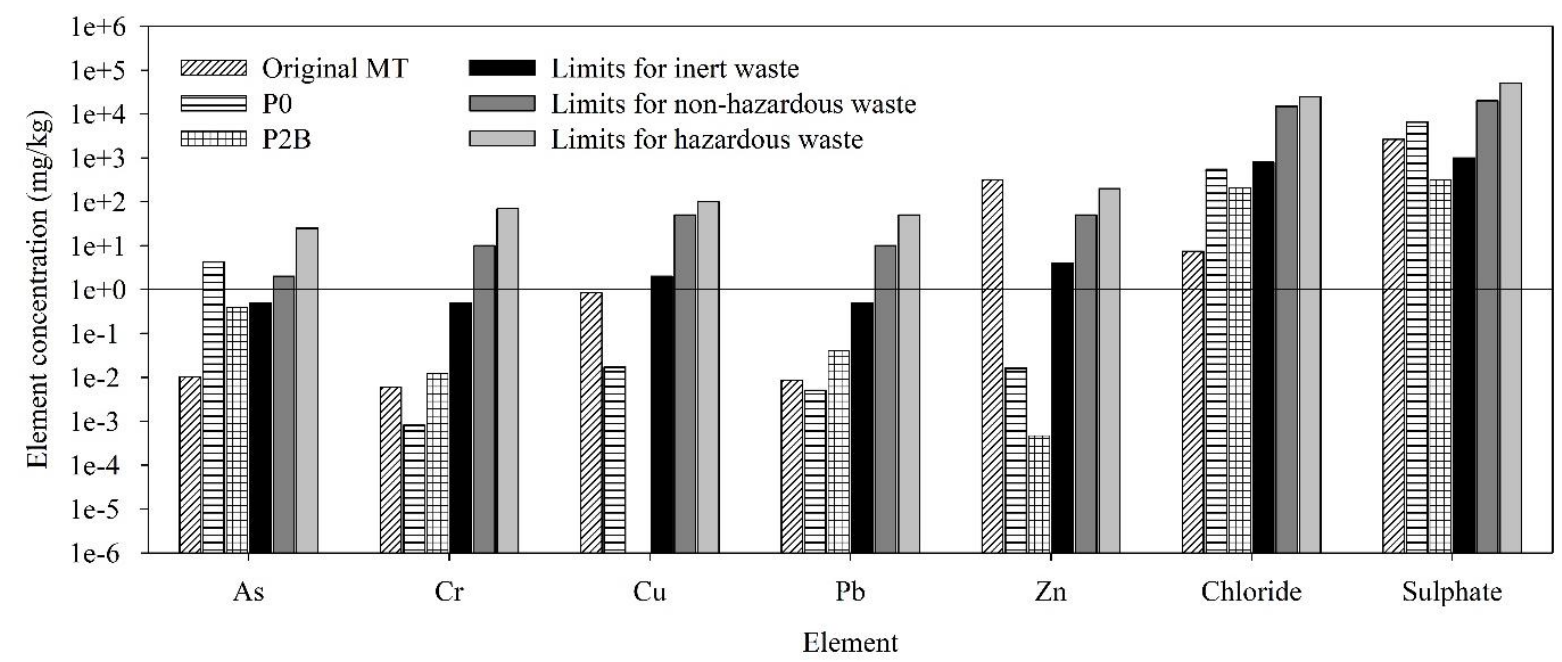

Figure 12. Element concentrations in the leaching solution (test LTT1) obtained from paste P2B and in comparison with the acceptance limits defined in 2003/33/EC.

The solubility of paste P2B was evaluated for up to 28 days (readings taken after 3, 7, 14, and 28 days) by submerging a monolith-type specimen in deionised water (LTT2 test). The leaching solution was not refreshed after each sample collection, meaning that the leachate ions were able to accumulate. The decision of not refreshing the solution was made to enable the detection of a potential leaching asymptotic level, as described by Zheng et al. [51]. The results are presented in Figure 13, together with the threshold values for non-hazardous waste.

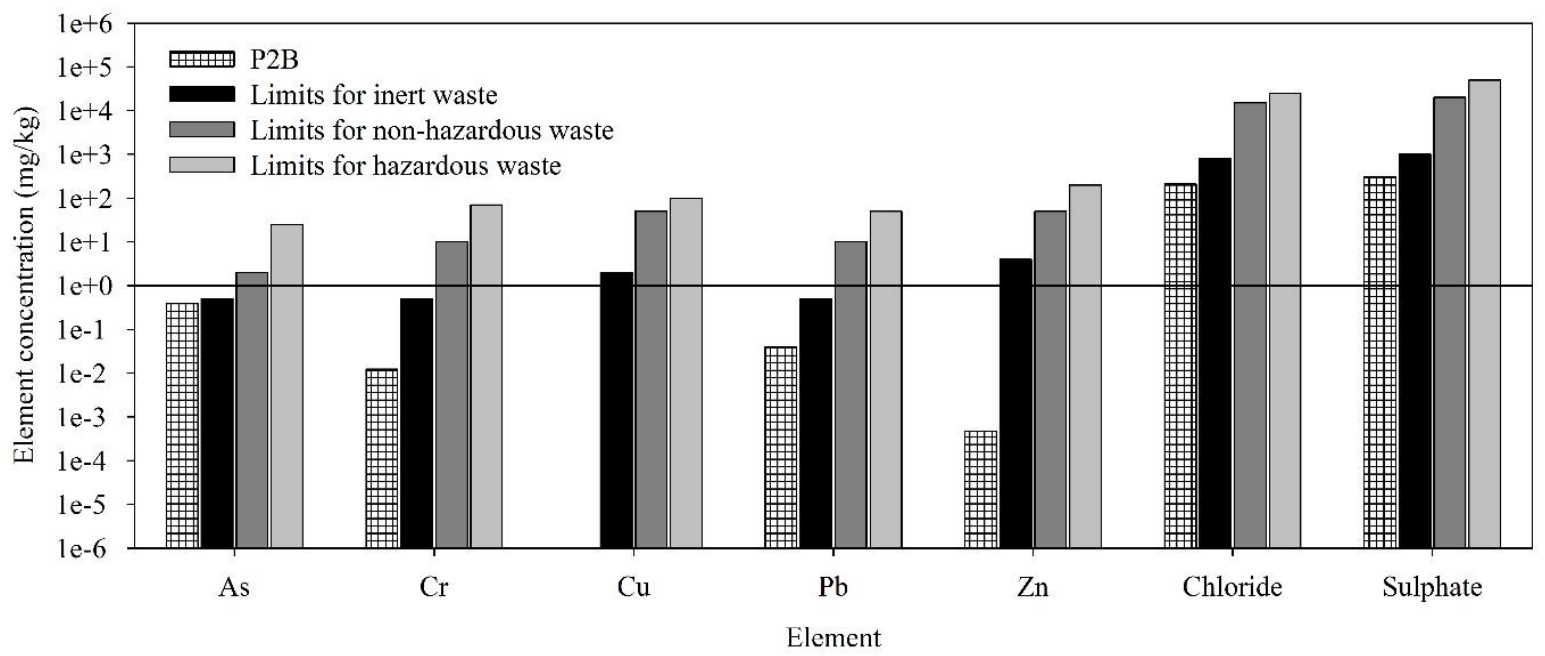

Figure 13. Concentration evolution in the solution where the paste P2B was submerged (LTT2), compared with the waste acceptance limits (2003/33/EC) for non-hazardous waste.

The $\mathrm{pH}$ of the solution decreased with time (Table 6), which could be a consequence of the consumption of $\mathrm{OH}^{-}$ions during the dissolution of $\mathrm{Si}$ and $\mathrm{Al}$ species [52], reinforced by the reduced amorphous calcium content [53]. Cihangir et al. [16] obtained a $\mathrm{pH}$ reduction throughout 360 days, from 12.5 to 11.2, of copper-zinc tailings stabilised with sodium-silicate-activated slag, which was attributed to the formation of acid via the oxidation of pyrite. Although in this case the $\mathrm{pH}$ reduction occurred in different curing conditions $\left(20^{\circ} \mathrm{C}\right.$ and $\left.85 \% \mathrm{RH}\right)$, a similar origin (pyrite oxidation) is plausible. 
Table 6. $\mathrm{pH}$ of the solution at the time of sampling (LTT2).

\begin{tabular}{cccc}
\hline \multicolumn{4}{c}{ Collection Period } \\
\hline $\mathbf{3 ~ d}$ & $\mathbf{7 ~ d}$ & $\mathbf{1 4} \mathbf{d}$ & $\mathbf{2 8 ~ d}$ \\
\hline 11.50 & 11.03 & 10.72 & 10.08 \\
\hline
\end{tabular}

The leaching LTT2 test results were compared with the soluble $\mathrm{SO}_{3}$ values measured directly from the water collected in the pond and from a sample of MT that was submerged in water for 28 days upon arrival to the laboratory (Figure 14). The value obtained after 28 days is comprehensively lower that the value obtained from the pond, while the value obtained in the LTT2 test is even lower (approximately $45 \%$ ) than the 28-day solubility, confirming the effectiveness of the stabilisation in terms of environmental performance. The figure also presents the conductivity measured in the same samples. In this case, the value measured in the water from the LTT2 test was significantly increased relative even to the pond water. This is most likely explained by the addition of fly ash, which generated a conductivity value in the submersion water higher than that in the water from the MT.

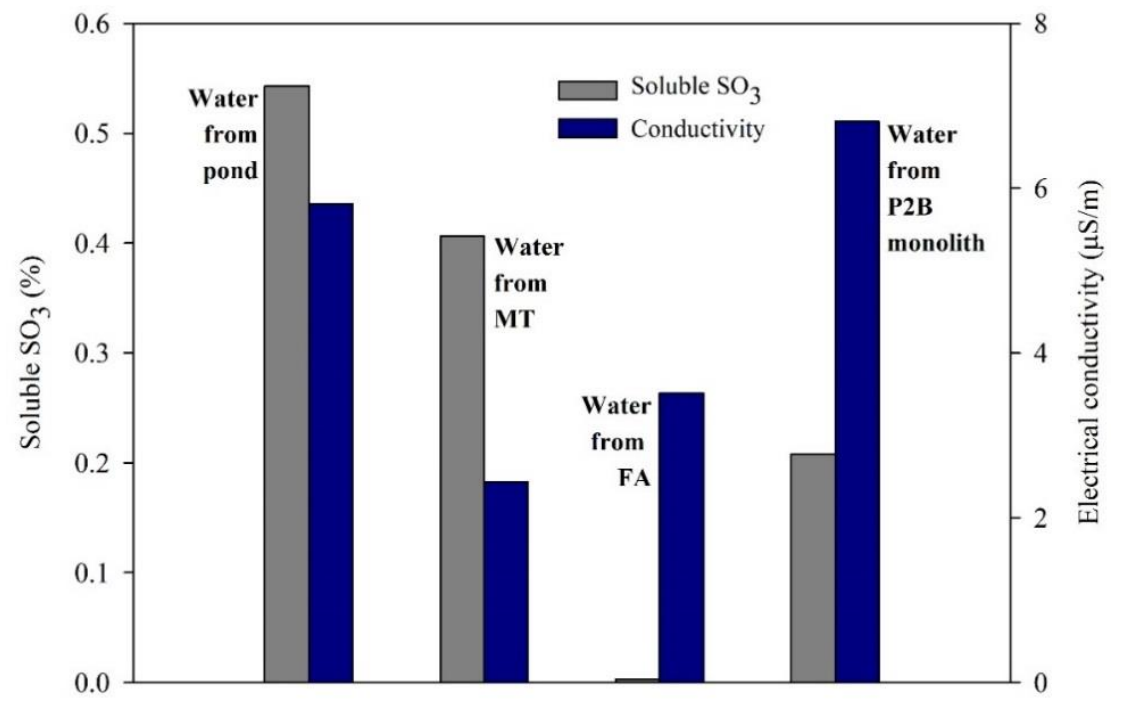

Figure 14. Comparison of the soluble $\mathrm{SO}_{3}$ and electrical conductivity measured in the water from the mine ponds, in the water where the original MT and FA were submerged for 28 days, and in the water where a P2B monolith was submerged for 28 days.

\section{Discussion}

The MT recovered from the Neves Corvo operation is a very interesting material in terms of density and mechanical behaviour, thus showing high potential for the construction industry. However, it bears a prohibitive environmental toll that needs to be significantly mitigated before it can be used. This motivation is also supported by the financial and environmental costs that are associated with the current landfilling of MT.

Although the MT was successfully activated with a 12.5 molal sodium hydroxide solution, without the addition of a second (and more effective) precursor or a thermal pretreatment, it still presented a low UCS, and its metal ion immobilisation was less than ideal. The reaction products included sodium sulphate carbonate in the form of burkeite $\left(\mathrm{Na}_{6}\left(\mathrm{CO}_{3}\right)\left(\mathrm{SO}_{4}\right)_{2}\right)$.

In order to improve both the mechanical and environmental performance, a second residue (FA) was added to the MT as a precursor. The results showed that an increase in the FA/MT ratio produced only a slight strength improvement, justifying the choice of an average FA/MT ratio (which favours the disposal of MT) for the environmental tests. The most influential variable on UCS was the activator's $\mathrm{NaOH}$ concentration, with the 15 molal paste showing the highest strength. However, the values 
obtained with concentrations below 15 molal are considered acceptable for several civil engineering applications (e.g., road base and sub-base; structural embankments; backfill material); thus, paste P2B (12.5 molal) was chosen for environmental testing.

The FTIR spectra showed that S-O bonds present in the original (anhydride) MT were broken in three of the four pastes tested (including P2B), suggesting the release of sulphur ions during the dissolution stage of the reactions. X-ray diffractograms detected the presence of burkeite in the pastes, a new mineralogical phase which is essentially sodium sulphate, as a result of the combination of the sulphate and sodium ions.

Based on the SEM/EDX data, direct activation of the MT (i.e., without FA) produced N-A-S-H gel, responsible for the strength development showed by this paste. The same gel was also developed in the FA/MT pastes. Since alkalis could neutralise the acidic environment generated by the oxidation, the lower the alkali content, the faster it became depleted during this neutralisation process; thus, a lower activation degree of the FA was achieved. Therefore, the dissolution process was taken further in the $\mathrm{P} 2 \mathrm{~B}$ paste than in any of the remaining pastes. Additional evidence of this behaviour was obtained when measuring the $\mathrm{pH}$ of the solution used for the LTT2 test, performed during 28 days on a P2B specimen (Table 6), since the $\mathrm{pH}$ reduction can be explained by the progressive oxidation of pyrite.

A comparison between both types of leachate tests revealed some similarity in terms of aggressiveness, since the values registered with the LTT1 test (which takes approximately $24 \mathrm{~h}$ to develop) are, in general, similar to the values obtained after 3 days in the LTT2 test. The solubility of the $\mathrm{Cr}, \mathrm{Cu}, \mathrm{Pb}$, and $\mathrm{Zn}$ ions did not change significantly between 3 and 14 days, suggesting a rapid surface removal of these species after only 3 days. The exception to this trend was As, which presented a relevant solubility increase between 3 and 14 days, up to a point where even the 2003/33/EC normative As threshold for non-hazardous waste was exceeded. After 28 days, the solubility increase was even more dramatic and, in this case, occurred also with the $\mathrm{Pb}$ and $\mathrm{Zn}$ ions. This process is probably governed by diffusion [54], although a possible failure of the physical encapsulating structure (i.e., local breakage that exposed some previously protected ions) should not be ignored [55].

The As leached from the original MT was below the thresholds proposed for inert, non-hazardous, and hazardous waste. However, after activation (P0), the increase in As solubility was very significant, surpassing not only the inert limit but also the non-hazardous limit. The difficulty in fixating As ions in aluminosilicate matrixes is well known [54,56], although this behaviour tends to improve with time $[38,57]$. It is related with the oxidation of the As ion, capable of assuming different oxyanoin forms, which possess very high solubility in alkaline environments but, nevertheless, are not bound to the final aluminosilicate matrix [57]. Therefore, it is possible that the increased alkalinity, as a result of the addition of the activator, favoured the release of As ions. This increased arsenic solubility was reverted again for paste $\mathrm{P} 2 \mathrm{~B}$, suggesting that the addition of a more effective precursor to the original MT (fly ash) resulted in the production of a higher volume of AA gel, which was then capable of containing the As ions more effectively than paste P0.

It is somewhat worrying that the LTT1 test, which is strongly based on standard EN 12457-4, was not able to detect the solubility levels of this particularly threatening element, revealed only by the LTT2 test, although it is reasonable to assume that the LTT2 conditions might be too extreme and, thus, hardly representative of the real field environment.

Regarding the immobilization of the $\mathrm{Cr}, \mathrm{Cu}, \mathrm{Pb}$, and $\mathrm{Zn}$ species, with all of them showing leachate values below the normalized limits, Lee et al. [50] sustained that geopolymers can immobilise lead ions through a combination of physical encapsulation and chemical bonding. Zhang et al. [55] observed a similar combination when studying the geopolymer immobilisation of $\mathrm{Cr}, \mathrm{Cd}$, and $\mathrm{Pb}$, and concluded that the predominant mechanism depends on the solubility level of the heavy metal ions, i.e., highly soluble salts are more spread throughout the matrix, while less soluble salts form higher-volume nuclei which are then involved by the gel matrix. However, García-Lodeiro et al. [58] showed that the inclusion of such metals like $\mathrm{Cr}$ and $\mathrm{Pb}$ in cementitious gel may decline in the presence of chloride ions (due to their interaction and subsequent formation of soluble chlorides), which would then increase their 
leaching. Studies regarding the immobilisation of $\mathrm{Cr}$ in alkali-activated fly ash systems have shown that this ion has a negative effect on the activation mechanism and, subsequently, on the hardening process, and is thus not very efficiently contained in the geopolymeric matrix [55,59]. Nevertheless, the maximum $\mathrm{Cr}$ solubility values found in the present work are well under the non-hazardous waste limit established in the 2003/33/EC normative. The above-mentioned papers also concluded that $\mathrm{Pb}$ is very effectively immobilised in aluminosilicate gel, which is in accordance with the present data, even if a substantial increase was obtained between 14 and 28 days.

The leaching potential of some inorganic ions $(\mathrm{Ca}, \mathrm{Fe}, \mathrm{K}, \mathrm{Mg}$, and $\mathrm{Na}$ ) not listed in the acceptance criteria defined in the normative 2003/33/EC are presented in Table 7. Decreasing release rates were registered for the $\mathrm{Ca}, \mathrm{Mg}$, and $\mathrm{Na}$ species as a consequence of their fixation, while the $\mathrm{Fe}$ and $\mathrm{K}$ species showed increasing solubility, most likely due to the oxidation of pyrite. It is noteworthy that the test was "static" (water was not changed after sampling), which allowed the saturation of the leachant and subsequent ion precipitation.

Table 7. Solubility of PB2 species not included in 2003/33/EC.

\begin{tabular}{cccccc}
\hline \multirow{2}{*}{ Element } & \multirow{2}{*}{ TTT1 $\mathbf{( m g} / \mathbf{k g})$} & \multicolumn{4}{c}{ LTT2 $\mathbf{( m g} / \mathbf{k g})$} \\
\cline { 3 - 6 } & & $\mathbf{3 ~ d}$ & $\mathbf{7 ~ d}$ & $\mathbf{1 4} \mathbf{~ d}$ & $\mathbf{2 8 ~ d}$ \\
\hline $\mathrm{Ca}$ & 6.58 & 2.67 & 2.27 & 1.77 & 1.67 \\
$\mathrm{Fe}$ & 4.08 & 1.33 & 2.21 & 3.83 & 8.46 \\
$\mathrm{~K}$ & 16.74 & 20.01 & 22.52 & 21.85 & 24.80 \\
$\mathrm{Mg}$ & 2.37 & 2.09 & 1.72 & 1.75 & 1.13 \\
$\mathrm{Na}$ & 2254.9 & 1891.2 & 1882.2 & 1634.5 & 1274.5 \\
\hline
\end{tabular}

No specific crystalline phases containing $\mathrm{As}, \mathrm{Cr}, \mathrm{Cu}, \mathrm{Pb}$, or $\mathrm{Zn}$ were detected in the XRD diffractograms or FTIR spectra, which might indicate that no specific chemical compound was formed between these metals and, for instance, silicon-a conclusion that was confirmed by the EDX analysis. However, it is also plausible that the concentration of these elements in the original MT is too low, meaning that even if any compound was formed after activation, it is possible that it was below the detection limit. Such a lack of association was also observed by Lee et al. [50] when studying the effect of lead on geopolymers with a Si/Al ratio of 2 . Although the sulphate leaching presented in Section 3.3 was below the normative limits, it is still significant nonetheless, implying that full isolation of these ions was not achieved. Nevertheless, it can be concluded that it is possible to stabilise acidic mine tailings from copper and zinc explorations using alkali-activated binary blends.

\section{Conclusions}

In terms of mechanical behaviour, the stabilisation of mine tailings from copper extraction using alkali-activated FA is an effective procedure which can be considered for low-strength applications $(<20 \mathrm{MPa})$, like embankments or road bases. This procedure has the advantage of avoiding thermic treatment to increase the amorphisation level, while requiring only $25 \%-30 \% \mathrm{FA}$, i.e., $70 \%-75 \%$ of the paste will be tailings. This is significant since it represents an alternative to traditional landfilling, and it also reduces cement consumption. Considering that the above-mentioned applications require high volumes of material, this solution represents a suitable alternative to conventional binders in terms of mechanical properties, environmental friendliness, and cost-effectiveness. A UCS of $15 \mathrm{MPa}$ was obtained after a curing period of $24 \mathrm{~h}$ at $85^{\circ} \mathrm{C}$ using a 15 molal SH activator (P2C). However, the $\mathrm{P} 2 \mathrm{~B}$ paste was chosen for further analyses, since its strength/cost compromise was considered to be more effective. The results showed that strength increase is related with the formation of $\mathrm{N}-\mathrm{A}-\mathrm{S}-\mathrm{H}$ gel, although sodium sulphate carbonate is also developed, suggesting that the total sodium input could be optimized without strength loss. The solubility of all the metals analysed in the P2B paste (78\%MT/22\%FA) was below the threshold for non-hazardous waste. However, additional environmental studies are required to validate this technique, especially considering the $\mathrm{SO}_{3}$ contents in the tailings. 
Author Contributions: Conceptualization, N.C. and M.O.; methodology, N.C. and J.C.; validation, A.F.-J., N.C.C. and Á.P.; formal analysis, N.C. and A.F.-J.; investigation, J.C.; resources, N.C., A.F.-J. and M.O.; data curation, J.C. and N.C.C.; writing-original draft preparation, N.C.; writing—review and editing, A.F.-J. and Á.P.; supervision, N.C. and M.O.; project administration, N.C.; funding acquisition, N.C and M.O. All authors have read and agreed to the published version of the manuscript.

Funding: This work was supported by Portuguese funding through the Foundation for Science and Technology-FCT/MCTES (PIDDAC), within the framework of the R\&D Project "JUSTREST-Development of Alkali Binders for Geotechnical Applications Made Exclusively from Industrial Waste", reference PTDC/ECM-GEO/0637/2014.

Conflicts of Interest: The authors declare no conflict of interest. The funders had no role in the design of the study; in the collection, analyses, or interpretation of data; in the writing of the manuscript; or in the decision to publish the results.

\section{References}

1. Gorman, M.R.; Dzombak, D.A. A review of sustainable mining and resource management: Transitioning from the life cycle of the mine to the life cycle of the mineral. Resour. Conserv. Recycl. 2018, 137, $281-291$. [CrossRef]

2. Yellishetty, M.; Karpe, V.; Reddy, E.H.; Subhash, K.N.; Ranjith, P.G. Reuse of iron ore mineral wastes in civil engineering constructions: A case study. Resour. Conserv. Recycl. 2008, 52, 1283-1289. [CrossRef]

3. Kinnunen, P.; Ismailov, A.; Solismaa, S.; Sreenivasan, H.; Räisänen, M.L.; Levänen, E.; Illikainen, M. Recycling mine tailings in chemically bonded ceramics-A review. J. Clean. Prod. 2018, 174, 634-649. [CrossRef]

4. Edraki, M.; Baumgartl, T.; Manlapig, E.; Bradshaw, D.; Franks, D.M.; Moran, C.J. Designing mine tailings for better environmental, social and economic outcomes: A review of alternative approaches. J. Clean. Prod. 2014, 84, 411-420. [CrossRef]

5. Park, I.; Tabelin, C.B.; Jeon, S.; Li, X.; Seno, K.; Ito, M.; Hiroyoshi, N. A review of recent strategies for acid mine drainage prevention and mine tailings recycling. Chemosphere 2019, 219, 588-606. [CrossRef]

6. Samarakoon, M.H.; Ranjith, P.G.; Rathnaweera, T.D.; Perera, M.S.A. Recent advances in alkaline cement binders: A review. J. Clean. Prod. 2019, 227, 70-87. [CrossRef]

7. Pacheco-Torgal, F.; Castro-Gomes, J.; Jalali, S. Investigations about the effect of aggregates on strength and microstructure of geopolymeric mine waste mud binders. Cem. Concr. Res. 2007, 37, 933-941. [CrossRef]

8. Pacheco-Torgal, F.; Castro-Gomes, J.; Jalali, S. Properties of tungsten mine waste geopolymeric binder. Constr. Build. Mater. 2008, 22, 1201-1211. [CrossRef]

9. Pacheco-Torgal, F.; Castro-Gomes, J.; Jalali, S. Tungsten mine waste geopolymeric binder: Preliminary hydration products investigations. Constr. Build. Mater. 2009, 23, 200-209. [CrossRef]

10. Pacheco-Torgal, F.; Castro-Gomes, J.; Said, J. Durability and environmental performance of alkali-activated tunsten mine waste mortars. J. Mater. Civ. Eng. 2010, 22, 897-905.

11. Kastiukas, G.; Zhou, X.; Castro-gomes, J. Preparation conditions for the synthesis of alkali-activated binders using tungsten mining waste. J. Mater. Civ. Eng. 2017, 29, 1-9. [CrossRef]

12. Tchadjié, L.N.; Djobo, J.N.Y.; Ranjbar, N.; Tchakouté, H.K.; Kenne, B.B.D.; Elimbi, A.; Njopwouo, D. Potential of using granite waste as raw material for geopolymer synthesis. Ceram. Int. 2015, 42, 3046-3055. [CrossRef]

13. Zhang, L.; Ahmari, S.; Zhang, J. Synthesis and characterization of fly ash modified mine tailings-based geopolymers. Constr. Build. Mater. 2011, 25, 3773-3781. [CrossRef]

14. Kiventerä, J.; Golek, L.; Yliniemi, J.; Ferreira, V.; Deja, J.; Illikainen, M. Utilization of sulphidic tailings from gold mine as a raw material in geopolymerization. Int. J. Miner. Process. 2016, 149, 104-110. [CrossRef]

15. Cihangir, F.; Ercikdi, B.; Kesimal, A.; Turan, A.; Deveci, H. Utilisation of alkali-activated blast furnace slag in paste backfill of high-sulphide mill tailings: Effect of binder type and dosage. Miner. Eng. 2012, 30, 33-43. [CrossRef]

16. Cihangir, F.; Ercikdi, B.; Kesimal, A.; Deveci, H.; Erdemir, F. Paste backfill of high-sulphide mill tailings using alkali-activated blast furnace slag: Effect of activator nature, concentration and slag properties. Miner. Eng. 2015, 83, 117-127. [CrossRef]

17. Moukannaa, S.; Loutou, M.; Benzaazoua, M.; Vitola, L.; Alami, J.; Hakkou, R. Recycling of phosphate mine tailings for the production of geopolymers. J. Clean. Prod. 2018, 185, 891-903. [CrossRef] 
18. Sedira, N.; Castro-Gomes, J.; Magrinho, M. Red clay brick and tungsten mining waste-based alkali-activated binder: Microstructural and mechanical properties. Constr. Build. Mater. 2018, 190, 1034-1048. [CrossRef]

19. Capasso, I.; Lirer, S.; Flora, A.; Ferone, C.; Cioffi, R.; Caputo, D.; Liguori, B. Reuse of mining waste as aggregates in fly ash-based geopolymers. J. Clean. Prod. 2019, 220, 65-73. [CrossRef]

20. Ahmari, S.; Zhang, L. Utilization of cement kiln dust (CKD) to enhance mine tailings-based geopolymer bricks. Constr. Build. Mater. 2013, 40, 1002-1011. [CrossRef]

21. Ahmari, S.; Zhang, L. Durability and leaching behavior of mine tailings-based geopolymer bricks. Constr. Build. Mater. 2013, 44, 743-750. [CrossRef]

22. Ahmari, S.; Zhang, L. Production of eco-friendly bricks from copper mine tailings through geopolymerization. Constr. Build. Mater. 2012, 29, 323-331. [CrossRef]

23. Ahmari, S.; Zhang, L.; Zhang, J. Effects of activator type/concentration and curing temperature on alkali-activated binder based on copper mine tailings. J. Mater. Sci. 2012, 47, 5933-5945. [CrossRef]

24. Shi, C.; Fernández-Jiménez, A. Stabilization/solidification of hazardous and radioactive wastes with alkali-activated cements. J. Hazard. Mater. 2006, 137, 1656-1663. [CrossRef]

25. El-Eswed, B.I.; Yousef, R.I.; Alshaaer, M.; Hamadneh, I.; Al-Gharabli, S.I.; Khalili, F. Stabilization/solidification of heavy metals in kaolin/zeolite based geopolymers. Int. J. Miner. Process. 2015, 137, 34-42. [CrossRef]

26. Chen, J.; Wang, Y.; Wang, H.; Zhou, S.; Wu, H.; Lei, X. Detoxification/immobilization of hexavalent chromium using metakaolin-based geopolymer coupled with ferrous chloride. J. Environ. Chem. Eng. 2016, 4, 2084-2089. [CrossRef]

27. El-Eswed, B.I.; Aldagag, O.M.; Khalili, F.I. Efficiency and mechanism of stabilization/solidification of $\mathrm{Pb}(\mathrm{II})$, $\mathrm{Cd}(\mathrm{II}), \mathrm{Cu}(\mathrm{II}), \mathrm{Th}(\mathrm{IV})$ and $\mathrm{U}(\mathrm{VI})$ in metakaolin based geopolymers. Appl. Clay Sci. 2017, 140, 148-156. [CrossRef]

28. Xia, W.Y.; Feng, Y.S.; Jin, F.; Zhang, L.M.; Du, Y.J. Stabilization and solidification of a heavy metal contaminated site soil using a hydroxyapatite based binder. Constr. Build. Mater. 2017, 156, 199-207. [CrossRef]

29. Yu, Q.; Li, S.; Li, H.; Chai, X.; Bi, X.; Liu, J.; Ohnuki, T. Synthesis and characterization of Mn-slag based geopolymer for immobilization of Co. J. Clean. Prod. 2019, 234, 97-104. [CrossRef]

30. Maleki, A.; Hajizadeh, Z.; Sharifi, V.; Emdadi, Z. A green, porous and eco-friendly magnetic geopolymer adsorbent for heavy metals removal from aqueous solutions. J. Clean. Prod. 2019, 215, 1233-1245. [CrossRef]

31. Boca Santa, R.A.A.; da Silva, A.F.V.; Padoin, N.; Soares, C.; Riella, H.G. Novel porous geopolymeric formulation as green material applied to the recovery of contaminated effluent aiming environmental protection. J. Clean. Prod. 2019, 231, 395-405. [CrossRef]

32. Zhu, W.; Teoh, P.J.; Liu, Y.; Chen, Z.; Yang, E.H. Strategic utilization of municipal solid waste incineration bottom ash for the synthesis of lightweight aerated alkali-activated materials. J. Clean. Prod. 2019, 235, 603-612. [CrossRef]

33. Rasaki, S.A.; Bingxue, Z.; Guarecuco, R.; Thomas, T.; Minghui, Y. Geopolymer for use in heavy metals adsorption, and advanced oxidative processes: A critical review. J. Clean. Prod. 2019, 213, 42-58. [CrossRef]

34. Tian, X.; Rao, F.; León-Patiño, C.A.; Song, S. Effects of aluminum on the expansion and microstructure of alkali-activated MSWI fly ash-based pastes. Chemosphere 2020, 240, 124986. [CrossRef]

35. Donatello, S.; Fernández-Jiménez, A.; Palomo, A. An assessment of Mercury immobilisation in alkali activated fly ash (AAFA) cements. J. Hazard. Mater. 2012, 213-214, 207-215. [CrossRef] [PubMed]

36. Demir, F; Derun, E.M. Modelling and optimization of gold mine tailings based geopolymer by using response surface method and its application in Pb2+ removal. J. Clean. Prod. 2019, 237, 117766. [CrossRef]

37. Amari, S.; Darestani, M.; Millar, G.J.; Rintoul, L.; Samali, B. Microchemistry and microstructure of sustainable mined zeolite-geopolymer. J. Clean. Prod. 2019, 234, 1165-1177. [CrossRef]

38. Kiventerä, J.; Lancellotti, I.; Catauro, M.; Poggetto, F.D.; Leonelli, C.; Illikainen, M. Alkali activation as new option for gold mine tailings inertization. J. Clean. Prod. 2018, 187, 76-84. [CrossRef]

39. Huang, X.; Zhuang, R.L.; Muhammad, F.; Yu, L.; Shiau, Y.C.; Li, D. Solidification/stabilization of chromite ore processing residue using alkali-activated composite cementitious materials. Chemosphere 2017, 168, 300. [CrossRef]

40. Kuranchie, F.A.; Shukla, S.K.; Habibi, D. Utilisation of iron ore mine tailings for the production of geopolymer bricks. Int. J. Min. Reclam. Environ. 2016, 30, 92-114. [CrossRef]

41. Kuenzel, C.; Ranjbar, N. Dissolution mechanism of fly ash to quantify the reactive aluminosilicates in geopolymerisation. Resour. Conserv. Recycl. 2019, 150, 104421. [CrossRef] 
42. BSI EN 13286-53. Unbound and Hydraulically Bound Mixtures. Method for the Manufacture of Test Specimens of Hydraulically Bound Mixtures Using Axial Compression; British Standards Institution: London, UK, 2004.

43. BSI EN 12457-4. BS EN 12457-4:2002-Characterisation of Waste-Leaching-Compliance Test for Leaching of Granular Waste Materials and Sludges; British Standards Institution: London, UK, 2002; Volume 4.

44. BSI EN 16192. BS EN 16192: 2011—Characterization of Waste. Analysis of Eluates; British Standards Institution: London, UK, 2011.

45. EU. Council Decision 2003/33/EC of 19 December 2002; Official Journal of the European Union: Brussels, Belgium, 2003.

46. Fan, M.; Brown, R.C. Comparison of the loss-on-ignition and thermogravimetric analysis techniques in measuring unburned carbon in coal fly ash. Energy Fuels 2001, 15, 1414-1417. [CrossRef]

47. Payá, J.; Monzó, J.; Borrachero, M.V.; Perris, E.; Amahjour, F. Thermogravimetric methods for determining carbon content in fly ashes. Cem. Concr. Res. 1998, 28, 675-686. [CrossRef]

48. Lei, C.; Yan, B.; Chen, T.; Quan, S.X.; Xiao, X.M. Comprehensive utilization of lead-zinc tailings, part 1: Pollution characteristics and resource recovery of sulfur. J. Environ. Chem. Eng. 2015, 3, 862-869. [CrossRef]

49. Ouellet, S.; Bussière, B.; Mbonimpa, M.; Benzaazoua, M.; Aubertin, M. Reactivity and mineralogical evolution of an underground mine sulphidic cemented paste backfill. Miner. Eng. 2006, 19, 407-419. [CrossRef]

50. Lee, S.; van Riessen, A.; Chon, C.M.; Kang, N.H.; Jou, H.T.; Kim, Y.J. Impact of activator type on the immobilisation of lead in fly ash-based geopolymer. J. Hazard. Mater. 2016, 305, 59-66. [CrossRef]

51. Zheng, L.; Wang, W.; Shi, Y. The effects of alkaline dosage and Si/Al ratio on the immobilization of heavy metals in municipal solid waste incineration fly ash-based geopolymer. Chemosphere 2010, 79, 665-671. [CrossRef]

52. Ye, N.; Chen, Y.; Yang, J.; Liang, S.; Hu, Y.; Xiao, B.; Huang, Q.; Shi, Y.; Hu, J.; Wu, X. Co-disposal of MSWI fly ash and Bayer red mud using an one-part geopolymeric system. J. Hazard. Mater. 2016, 318, 70-78. [CrossRef]

53. Qiang, T.; Heejong, K.; Kazuto, E.; Takeshi, K.; Toru, I. Size effect on lysimeter test evaluating the properties of construction and demolition waste leachate. Soils Found 2015, 55, 720-736. [CrossRef]

54. Fernández-Jiménez, A.; Palomo, A.; Macphee, D.E.; Lachowski, E.E. Fixing arsenic in alkali-activated cementitious matrices. J. Am. Ceram. Soc. 2005, 88, 1122-1126. [CrossRef]

55. Zhang, J.; Provis, J.L.; Feng, D.; van Deventer, J.S.J. Geopolymers for immobilization of Cr6+, Cd2+, and Pb2+. J. Hazard. Mater. 2008, 157, 587-598. [CrossRef] [PubMed]

56. Fernández-Jiménez, A.; Lachowski, E.E.; Palomo, A.; Macphee, D.E. Microstructural characterisation of alkali-activated PFA matrices for waste immobilisation. Cem. Concr. Compos. 2004, 26, 1001-1006. [CrossRef]

57. Kiventerä, J.; Sreenivasan, H.; Cheeseman, C.; Kinnunen, P.; Illikainen, M. Immobilization of sulfates and heavy metals in gold mine tailings by sodium silicate and hydrated lime. J. Environ. Chem. Eng. 2018, 6, 6530-6536. [CrossRef]

58. García-Lodeiro, I.; Carcelen-Taboada, V.; Fernández-Jiménez, A.; Palomo, A. Manufacture of hybrid cements with fly ash and bottom ash from a municipal solid waste incinerator. Constr. Build. Mater. 2016, 105, 218-226. [CrossRef]

59. Palomo, A.; Palacios, M. Alkali-activated cementitious materials: Alternative matrices for the immobilisation of hazardous wastes: Part II. Stabilisation of chromium and lead. Cem. Concr. Res. 2003, 33, $289-295$. [CrossRef]

(C) 2020 by the authors. Licensee MDPI, Basel, Switzerland. This article is an open access article distributed under the terms and conditions of the Creative Commons Attribution (CC BY) license (http://creativecommons.org/licenses/by/4.0/). 